\title{
Quantitative Evaluation of Weathering Degree through Fuzzy-AHP Method and Petrophysics Analysis for Sandstone Carvings
}

\section{Mingshen Shao}

Chinese Academy of Cultural Heritage

\section{Dong Xu}

Chinese Academy of Cultural Heritage

\section{Yuchao Wang ( $\square$ wangych2019@Izu.edu.cn )}

Lanzhou University https://orcid.org/0000-0001-8486-9333

\section{Ziyi Wang}

Chinese Academy of Cultural Heritage

\section{Xingzhou Liang}

Chinese Academy of Cultural Heritage

Li Li

Chinese Academy of Cultural Heritage

\section{Research Article}

Keywords: Jurassic sandstone, Sandstone carvings, non-destructive test, weathering degree, Fuzzy-AHP assessment.

Posted Date: August 17th, 2021

DOl: https://doi.org/10.21203/rs.3.rs-807988/v1

License: (9) This work is licensed under a Creative Commons Attribution 4.0 International License.

Read Full License

Version of Record: A version of this preprint was published at Natural Hazards on February 15th, 2022. See the published version at https://doi.org/10.1007/s11069-022-05238-6. 
1 Quantitative evaluation of weathering degree through Fuzzy-AHP

2 method and petrophysics analysis for sandstone carvings

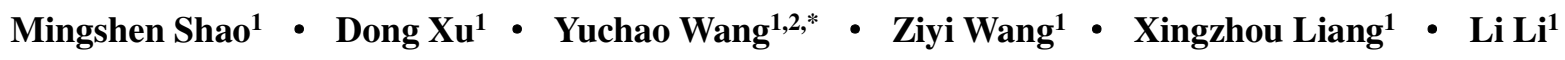

\section{Abstract}

Study on weathering degree assessment of sandstone carvings play an important role in scientific conservation. However, current state of research on weathering assessment cannot reach the needs of scientific evaluation. In this study, the selected sandstones originate from Jurassic and, soluble salt and acid simulation experiments were carried out on standard samples. The weight, specimen surface hardness, ultrasonic velocity and water absorption are measured by means of the non-destructive methods. Furthermore, mineral composition and petrophysical properties are analyzed on small specimens in laboratory. It is revealed that the main mineral, such as quartz and feldspar, is shown by oblate and prolate in shape. Moisture content has great influence on compressive strength of rock samples. Rock porosity increases with deterioration process. The decrease of quality, surface hardness and ultrasonic velocity with increasing cycles. Conversely, water absorption capillary increase over cycles. In addition, Fuzzy-AHP method is adopted to further evaluate weathering degree on experiment samples. Results in macroscopic show that the value of weathering degree is 0.3271 for sodium sulfate solution, which is shown by moderate weathering; 0.1951 for $\mathrm{pH}=1$ sulfuric acid and 0.1060 for $\mathrm{pH}=2$ sulfuric acid, which is characterized by low weathering; 0.0516 for $\mathrm{pH}=3$ sulfuric acid and 0.0421 for $\mathrm{pH}=4$ sulfuric acid, belonging to very low weathering.

Keywords Jurassic sandstone, Sandstone carvings, non-destructive test, weathering degree, FuzzyAHP assessment.

\section{Introduction}

In many cases damage to cultural heritage is caused by salt, rainwash and ice crystallization. The granular disintegration (Fig. 1a), tafoni (Fig. 1b), salt efflorescence (Fig. 1c), losing (Fig. 1d) and scaling (Fig. 1e) are representative examples of a deterioration that may be significantly influenced by rock weathering. Generally, Jurassic sandstone, being entirely crystalline, originates from geological periods between the Cretaceous and the Triassic. The rock fabric of sandstone, such as grain size, sorting and roundness, controls their petrophysical properties during deterioration. In addition, the 
swelling and shrinking of clay mineral and complex alteration could cause mic-cracking within rock

30 mass.

$31 \quad 1$
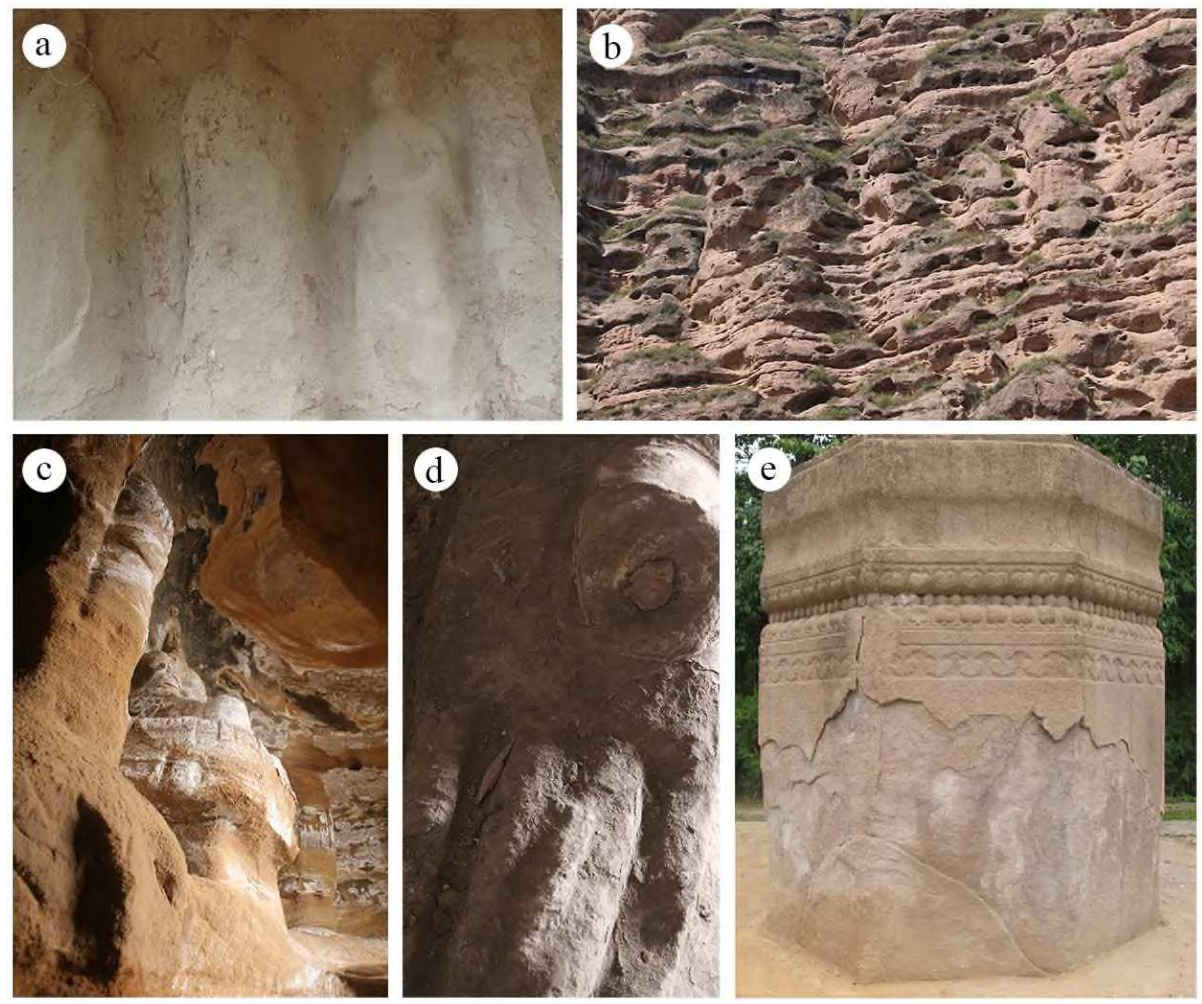

Fig. 1 Different weathering disease observed in sandstone. (a), (b) large granular disintegration and tafoni weathering in Bingling Temple, Northwest China; (c) is salt efflorescence developed on the rock surface in North Grottoes, (Qingyang, Northwest China); (d) loss damage on Jurassic sandstone in Chongqing and e scaling of strongly layered in Chengde.

Weathering of rocks caused by freeze-thaw (Piantelli et al. 2020; Tianbiao et al. 2016), salt crystallization (Jingke et al. 2021; Zhongjian et al. 2015), thermal shock (Murru et al. 2018) and dissolution (Lanqin et al. 2018) has been studied for many years. However, few studies have been focused on determination of the weathering degree, as it takes into consideration of massive weathering factors. Incipiently, typical cavernous weathering (i.e. 'Tafoni', 'honeycomb', 'alveolar' et.al) commonly occurs in sandstone and granitic outcrops, which have been described by Mustoe (1983)

\section{* Yuchao Wang \\ Wangych2019@1zu.edu.cn}

\footnotetext{
${ }^{1}$ Institute of conservation and restoration, Chinese Academy of Cultural Heritage, Beijing 100029, China

${ }^{2}$ Key Laboratory of Mechanics on Disaster and Environment in Western China, the Ministry of Education of China, and School of Civil Engineering and Mechanics, Lanzhou University, No. 222, Tianshui South Road, Lanzhou 730000, Gansu, China
} 
and analyzed by Mellor (1997), who stated that these weathering formation is initiated at weak points, then, elevated humidity may promote core softening, which in turn leads to further cavern enlargement (Alexandrowicz 1989). Afterwards, several researchers used chemical indices to determine weathering degree (Chiu and Ng 2014; Dong et al. 2015). In fact, it should be noted that chemical indices may change due to mineral transformation or replacement, they are not credible indicator to evaluate weathering degree. In addition, mechanical and physical properties of rocks, such as Schmidt hammer rebound value, P-wave velocity, porosity, compressive and tensile strength, predominantly control its physical behavior (Martinho et al. 2017; Wilhelm et al. 2016; Yun et al. 2021; Y1lmaz 2012). Hence, quantitative evaluation mainly used these physical indexes obtained from accelerated deterioration test in laboratory. As cultural relics are non-renewable resource, most researchers advise non-destructive methods to determine weathering degree of rock in site.

Heretofore, most of deterioration experiments under the influence of different environmental factors have studied. Weight, hardness, ultrasonic velocity et al. are common characterization indices. However, little research has been done on comprehensive analysis of these indices. In fact, it has become a key step to conduct comprehensive assessment on sandstone carvings before carrying out detailed scientific conservation work. Therefore, exploring a suitable approach to assess the weathering degree of carving still need to discuss. Originally, Saaty advocated the Analytical Hierarchy Process (AHP) for the first time in 1979 (Saaty 1979; Wind and Satty 1980). It is widely used for risk prediction and geo-environmental assessment due to it efficient of dealing qualitative data (Alshehri et al. 2015; Ercanoglu et al. 2008; Nefeslioglu et al. 2013; Ramkar and Yadav 2021). However, AHP method cannot reflect actual human thinking style and assessment results always become subjective and imprecise. Hence, Zadeh (1973) further proposed fuzzy theory combined with AHP to improve the flexibility in judgment and decision. Furthermore, recent studies reveal that Fuzzy-AHP method is successful applied on natural hazards assessment (Hategekimana et al., 2018; Rezaei et al. 2019; Xiaoling et al. 2013).

In this study, Fuzzy-AHP method was adopted to determine the weathering degree. Sodium sulfate solution and sulfuric acid were selected to conduct simulation experiment. Four $\mathrm{pH}$ gradients ( $\mathrm{pH}=1,2,3$ and 4) are set. In addition, specimens selected from Jurassic sandstone were conducted nondestructive test, including surface hardness, ultrasonic velocity, penetration coefficient, photomicrograph and quality. Both these indicators were collected of deterioration. Afterwards, AHP was used to determine the weights in hierarchical framework of the weathering degree assessment. 
Finally, FAHP was adopted to calculate weathering degree assessment outcomes. Furthermore, this method on weathering indices will further promote the scientific conservation of future geotechnical heritage.

\section{Material and experiment}

\subsection{Petrophysical properties}

Danzishi rock carving was located in Nanan district, Chongqing, which excavated in quartz arkose of Jurassic age. Furthermore, lots of statues were carved into the sandstone cliff of Jurassic stratum. Analysis of samples collected from Danzishi rock carving (Fig. 2) indicated predominantly sandy and/or massive texture, poor sorting and roudness. Table 1 provided details on sampling petrophysical properties.
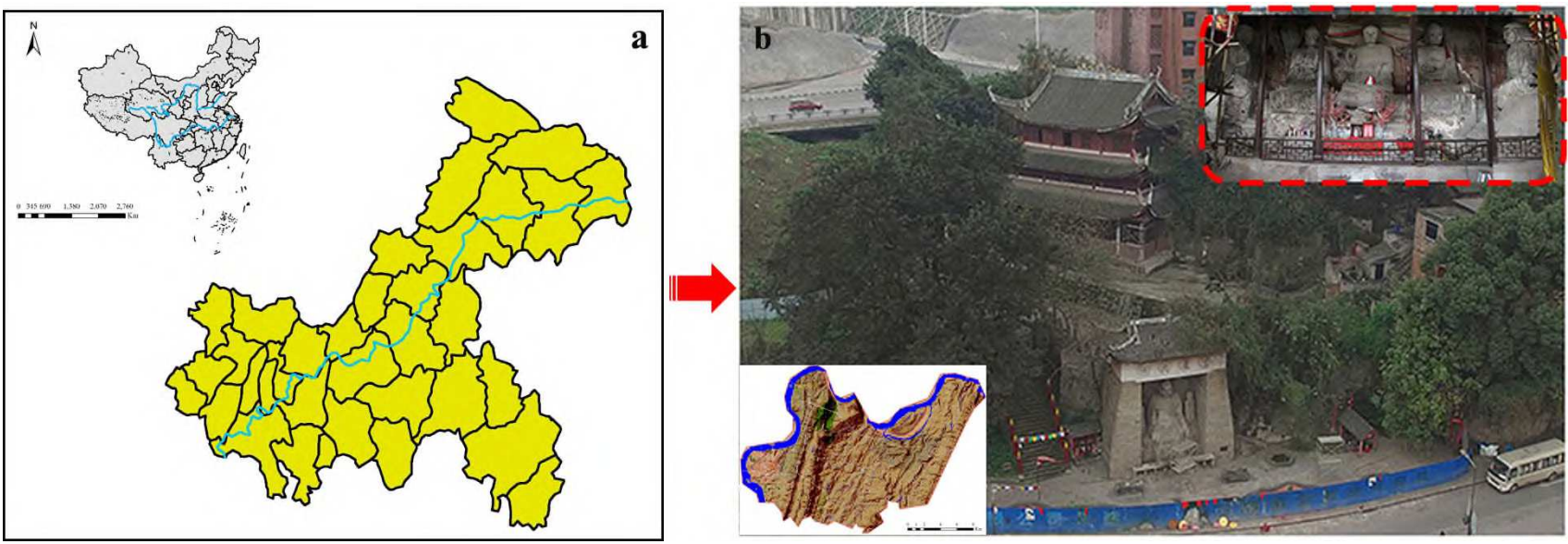

Fig. 2 Samples location. (a) Administrative division of China and Chongqing; (b) Danzishi rock carving.

Table 1 Basic petrophysical properties of samples

\begin{tabular}{|c|c|c|c|c|}
\hline $\operatorname{Density}\left(\mathrm{g} / \mathrm{cm}^{3}\right)$ & 2.45 & \multirow{3}{*}{$\begin{array}{c}\text { Compressive strength } \\
\text { (MPa) }\end{array}$} & Natural state & 32.41 \\
\hline Specific gravity & 2.65 & & Dry state & 28.89 \\
\hline Cohesion $(\mathrm{KPa})$ & 400 & & Saturated state & 15.59 \\
\hline Friction angle $\left(^{\circ}\right)$ & 35 & Porosity (\%) & & 10.85 \\
\hline
\end{tabular}

In addition, Jurassic sandstone (as shown in Fig. 3) mainly consists of medium-sized sand, quartz and feldspar, which differ among within themselves in that respect according to direction. Microscopically, the feldspar inclusions often show serictic alteration. Commonly, quartz shows idiomorphic to hypidiomorphic single crystal shapes, but it also occurs as polycrystalline quartz aggregates. Partial feldspar is often altered to Chlorite and epidote. In this matrix, plagioclase and quartz are dominant, and subordinated sericite and chlorite occur. In addition, quartz crystal exhibits a preferred grain orientation in oblate shape, while feldspar is characterized by a prolate fabric. 
94 Furthermore, discrete grains of minerals differ among themselves as to their coefficient of expansion, which cause the deterioration within rocks.

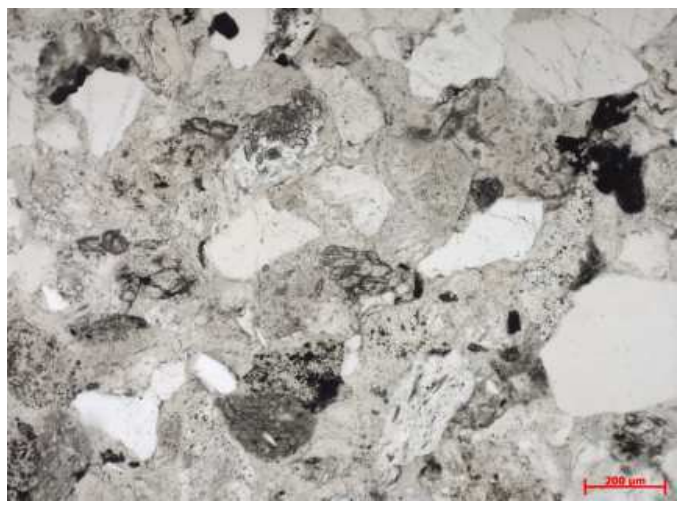

(a) observation under plane-polarized light

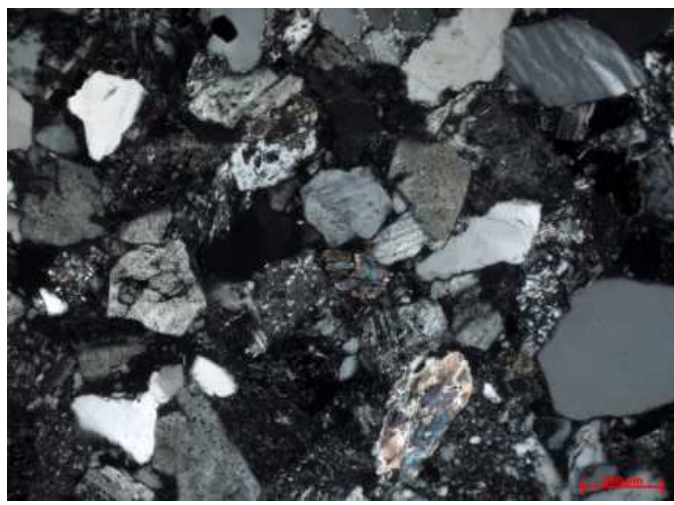

(b) observation under cross-polarized light

Fig. 3 Thin section observation with polarized light.

\subsection{Experiment conditions}

\subsubsection{Experiment schedule of sodium sulfate solution}

According to testing report of study area, sodium sulfate with 5 percentage concentration was selected to conduct simulation experiment on sample cubes $(10 \times 10 \times 10 \mathrm{~cm})$. Then, surface hardness, ultrasonic velocity and penetration coefficient were performed with non-destructive device, as shown in Fig. 4 . Sketch of experiment schedule were illustrated in Fig. 5. Samples were completely immersed in salt solution about $12 \mathrm{~h}$. Then, samples were dried in air oven at $80^{\circ} \mathrm{C}$ for 12 hours. Afterwards, specimens were removed from oven and cooled to air temperature for 12 hours. Finally, specimens were immersed in distilled water to dissolve surface salinity of samples. It should be emphasized that the hole process is one cycle, and each cycle as the equivalent of 3 days.

(a)

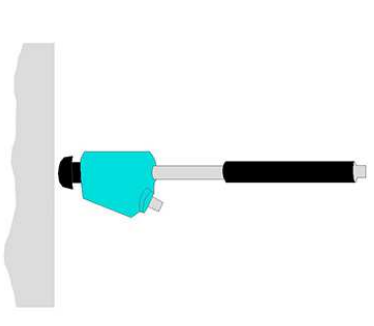

(b)

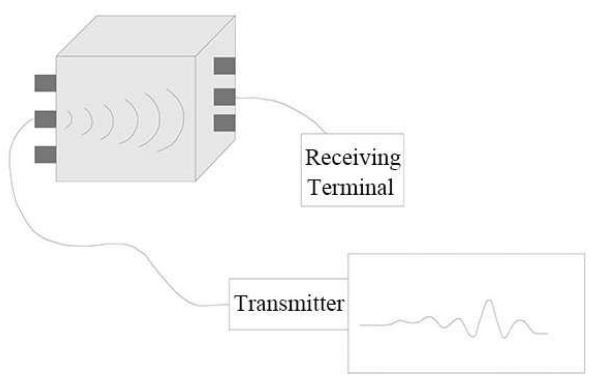

(c)

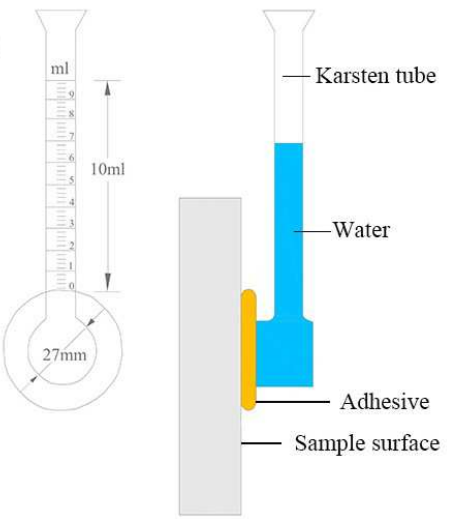

Fig. 4 Non-destructive test equipment. (a) surface hardness apparatus; (b) Measure the ultrasonic velocity of samples; (c) karsten tube test. 

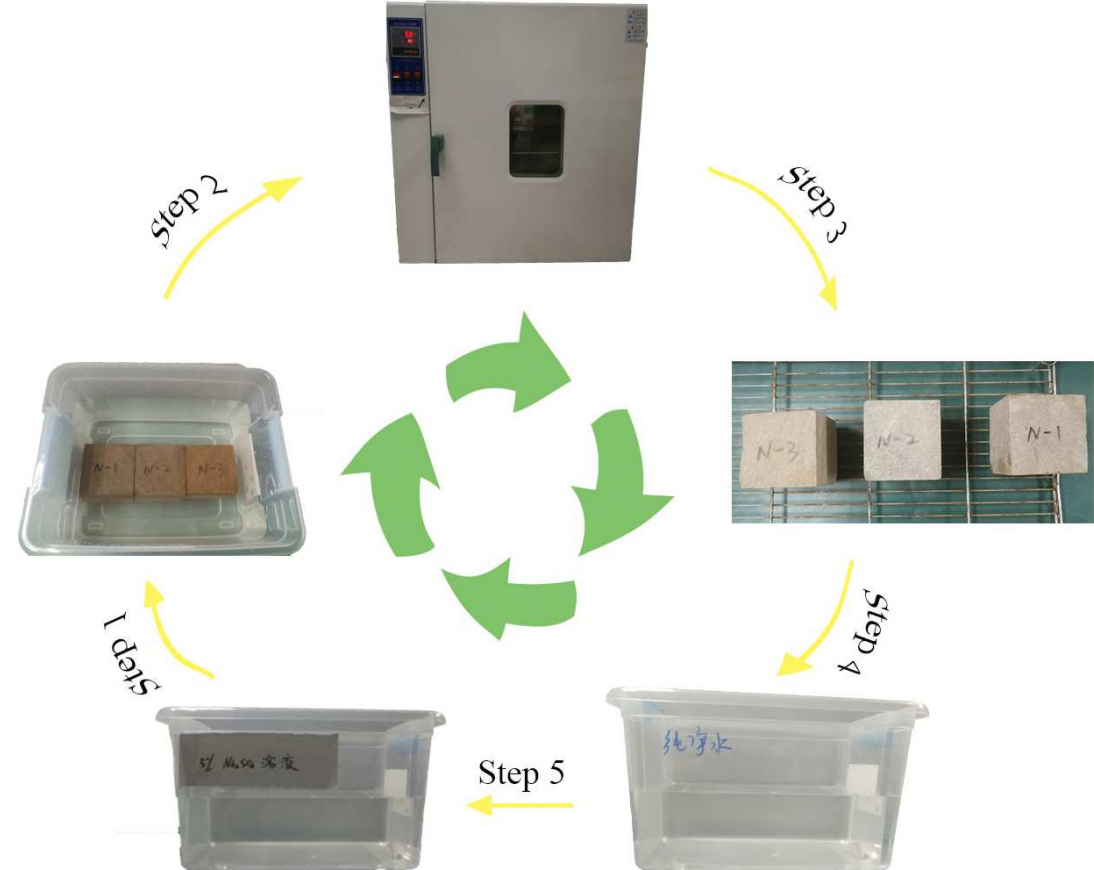

Step 5

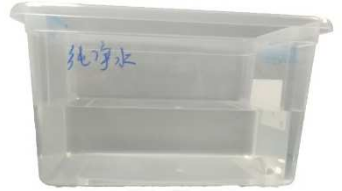

Fig. 5 Experiment schedule of sodium sulfate solution.

\subsubsection{Experiment schedule of sulfuric acid solution}

Likewise, dilute sulfuric acid was selected according to the hydrogen ion content in the testing report.

Four $\mathrm{pH}$ gradients ( $\mathrm{pH}=1,2,3$ and 4) were set on dilute sulfuric acid solution. As presented in Fig. 6, twelve cube samples were used, and divided into four groups. Each group cubes were immersed in sulfuric acid solution with different concentrations of hydrogen ions for 12 hours, dried for $12 \mathrm{~h}$ at air oven and then left to cool at air temperature for a further 12 hours. Afterwards, samples will return to their containers to soak for the further repeated cycle. Finally, hardness, ultrasonic and absorption test were performed by non-destructive methods after 9 cycles.
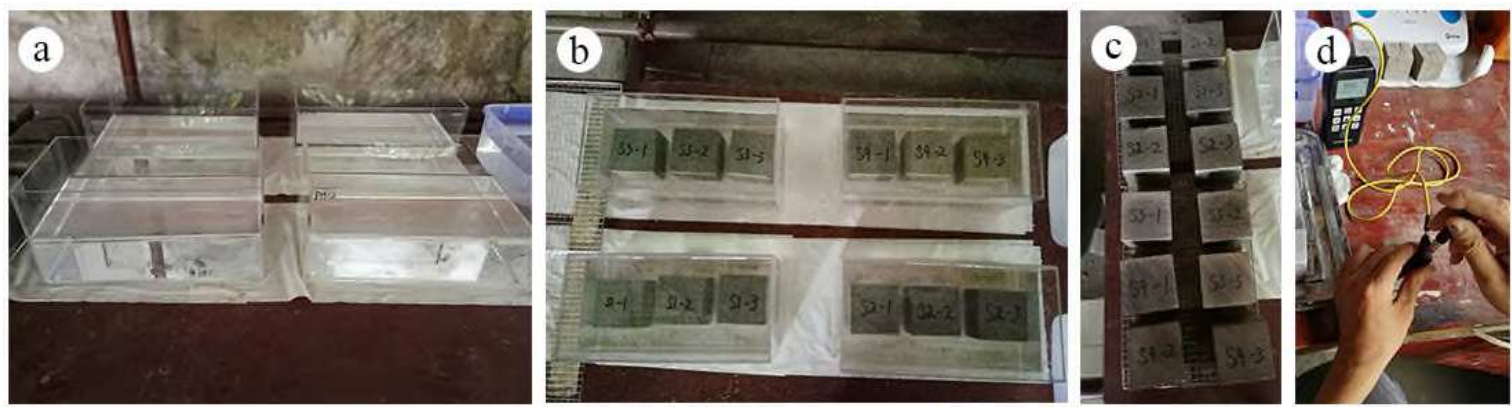

Fig. 6 Experiment schedule of dilute sulfuric acid solution.

\section{Results}

\subsection{Result of sodium sulfate solution}

As presented in Fig. 7, specimens subjected to salt damage is characterized by granular disintegration 
and scaling. It is interesting to note that there is a good correlation between grain size and water absorption. The sample with higher grain size exhibits higher water absorption. In addition, the change law of ultrasonic velocity, weight and hardness are shown in Fig. 7 (d), (e) and (f). Both of these indicators decrease over repeated cycles are observed. Decrease of weight and hardness are mainly caused by granular disintegration and scaling.
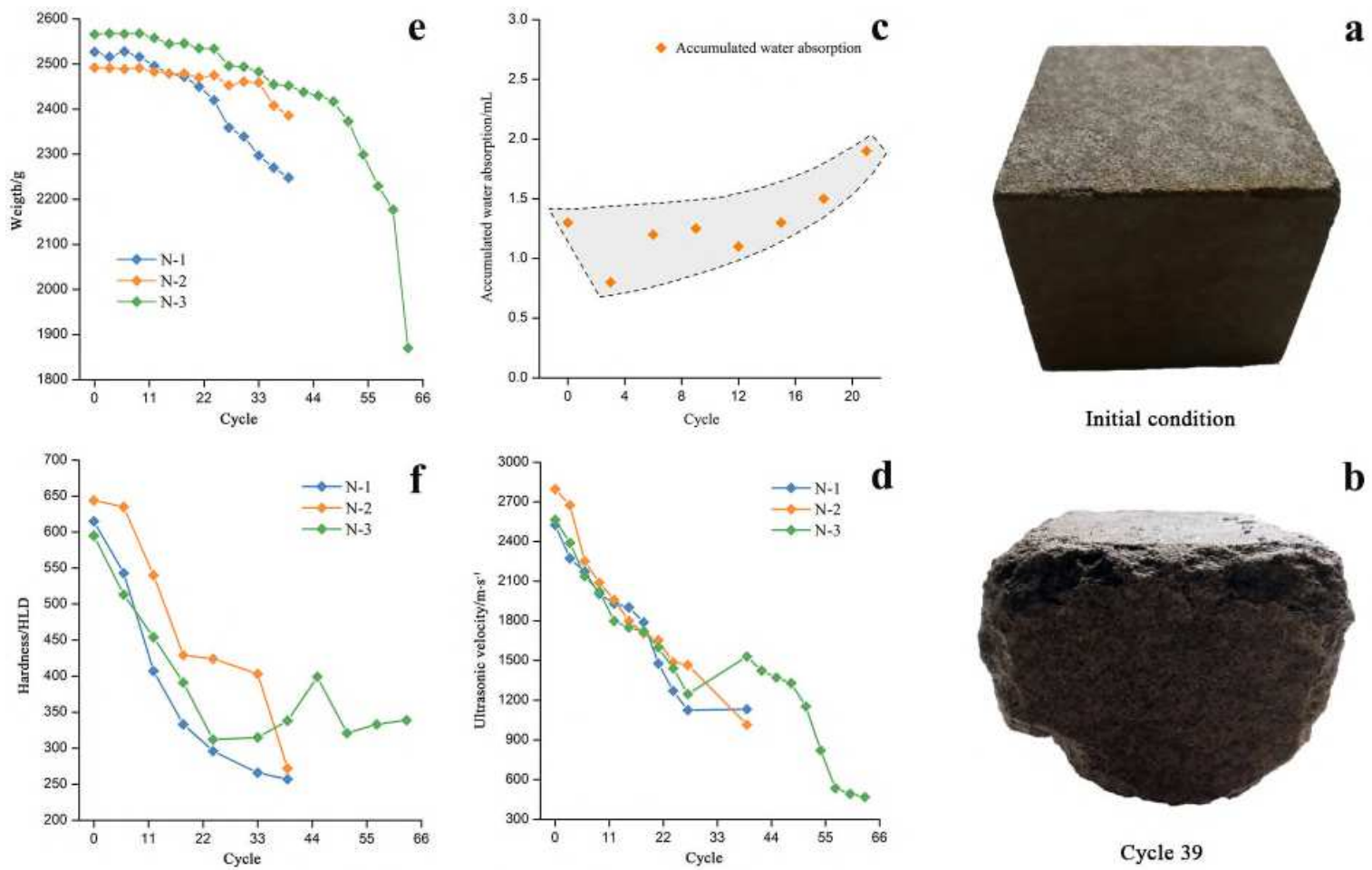

Figs. 7 (a-f) Damage phenomena and data statistics during salt crystallization test. (a) initial state; (b) weathering state after 39 repeated cycles; (c) water absorption changes; (d) ultrasonic velocity variation; (e) loss in weight; (f) hardness variation.

\subsection{Result of sulfuric acid solution}

Fig. 8 shows a clear law that hardness and ultrasonic velocity decreased over repeat cycles. Samples subjected more damage with higher hydrogen ion concentration. It is obvious to observe that the samples show higher degree of decrease of hardness and ultrasonic velocity. Damage degree of these samples varies strong to weak in the following order: $\mathrm{pH}=1, \mathrm{pH}=2, \mathrm{pH}=3$ and $\mathrm{pH}=4$. However, results do not exhibit a good law for specimen weight and water absorption. 

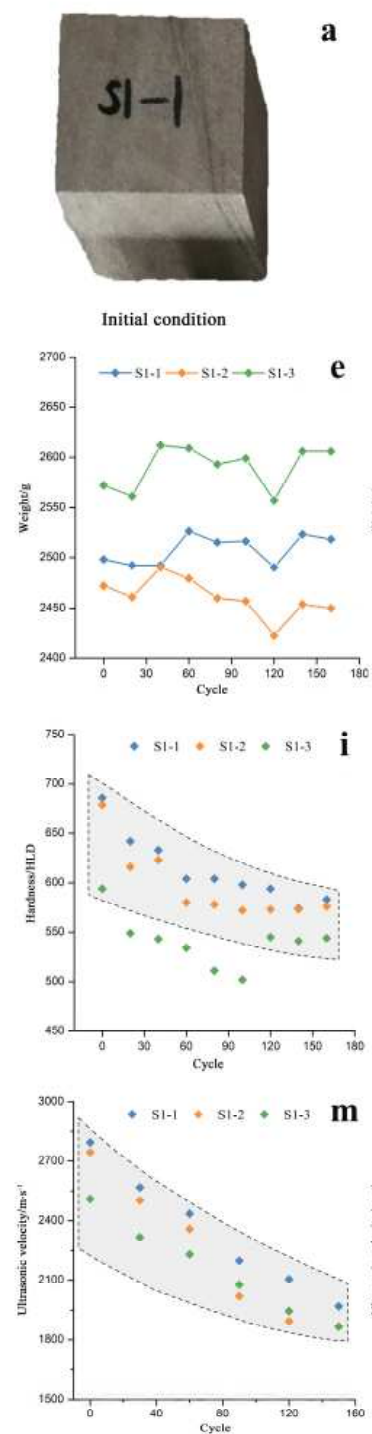

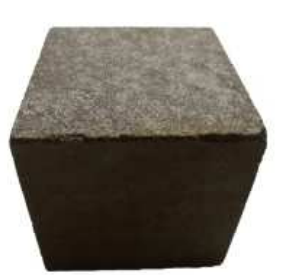

Cycle 40
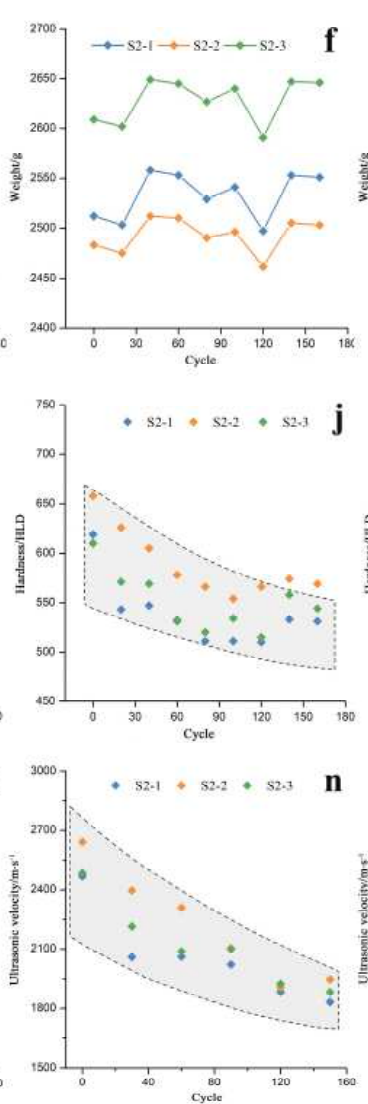

b

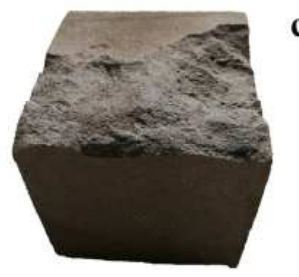

Cycle 120
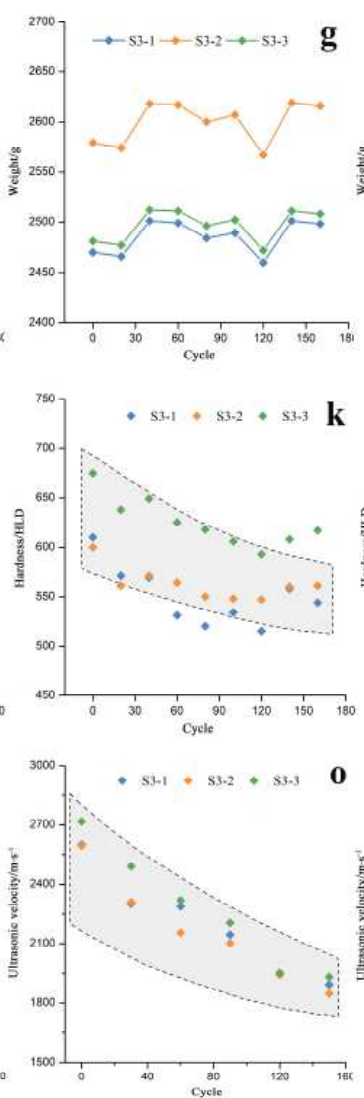

g
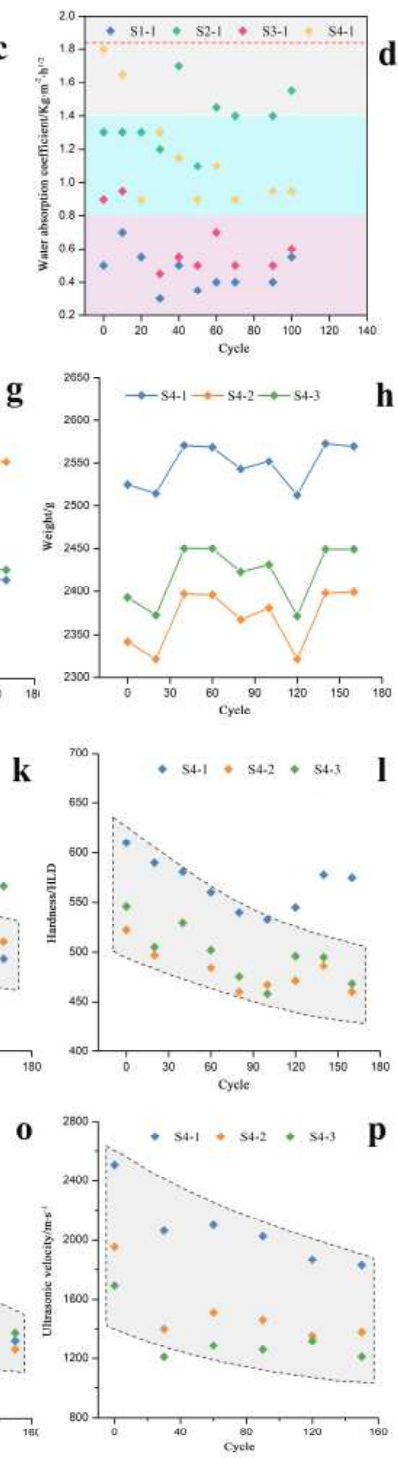

Figs. 8 (a-p) Damage phenomena and data statistics during dilute sulfuric acid solution attack. (a), (b), (c) initial and weathering state after a certain number of repeated cycles; d-respective variation of water absorption; (e), (f), (g), (h) loss in weight; (I), (j), (k), (l) hardness variation; (m), (n), (o), (p) ultrasonic velocity variation.

\section{Fuzzy-AHP assessment}

\subsection{Determine the hierarchical model}

146 For weathering assessment degree, the judgement of importance degree of different conditions is the

147 first step to assess weathering degree through weight calculation. In this study, this hierarchical model 148 includes three layers (as shown in Fig. 9): the first layer is called as goal layer (A), i.e., specimens 149 weathering degree in this study; the second one is criterion layer which indicates sodium sulfate 150 solution (B); the third layer, as well as index layer, contains the measuremental indicators, including surface hardness $\left(\mathrm{C}_{1}\right)$, ultrasonic velocity $\left(\mathrm{C}_{2}\right)$ and water absorption coefficient $\left(\mathrm{C}_{3}\right)$. 


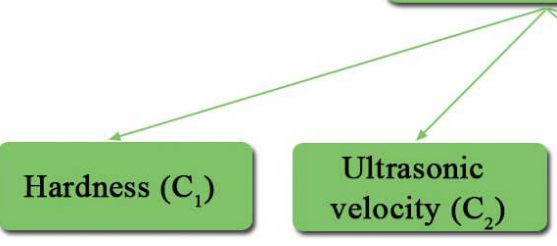

Fig. 9 The hierarchical model of weathering degree assessment.

\subsection{Determine the judgement matrix $(A)$ and the weight calculation}

Firstly, the weight judgment matrix can be established according to 1 to 9 degree compare method proposed by Saaty (2006). Afterwards, the weight of each layer, as well as the vector of weights, are calculated according to judgement matrix based on eigenvalue method (Shang et al. 2010):

$$
A \omega=\lambda_{\max } \omega
$$

Where $\omega=\left[\omega_{1}, \omega_{2}, \ldots, \omega_{n}\right]$ is the weight vector, $\lambda_{\max }$ is largest eigenvalue of matrix $\mathrm{A}$, which can be calculated by using the following equation:

$$
\lambda_{\max }=\frac{1}{n} \sum_{i=1}^{n} \frac{(A \omega)_{i}}{\omega_{i}}
$$

Furthermore, the element of weight vector should be normalized via the Equation:

$$
\sum_{i=1}^{n} \omega_{i}=1
$$

Actually, it should be noted that consistency check plays an important role in the whole process. The purpose of consistency check is to avoid the interference of other factors on reliability and accuracy of matrix ranking. The specific calculation formula is as follow:

$$
C R=\frac{C I}{R I}
$$

where $\mathrm{CI}$ is the consistency indicator, the value of $\mathrm{CI}$ is calculated by Equation (6). $R I$ is called random indicator and its value for different scales are presented in Table 2.

$$
C I=\left(\lambda_{\max }-n\right) /(n-1)
$$

Table. 2 The value of the random indicator $R I$

\begin{tabular}{cccccccccc}
\hline Scale & 1 & 2 & 3 & 4 & 5 & 6 & 7 & 8 & 9 \\
\hline RI & 0 & 0 & 0.58 & 0.90 & 1.12 & 1.24 & 1.32 & 1.41 & 1.45 \\
\hline
\end{tabular}

Therefore, we first rank the criteria level index in order of importance. The importance degree of different conditions varies from strong to weak in the following order: sodium sulfate solution, $\mathrm{pH}=1$ sulfuric acid, $\mathrm{pH}=2$ sulfuric acid, $\mathrm{pH}=3$ sulfuric acid and $\mathrm{pH}=4$ sulfuric acid. Furthermore, results of 
weight judgment matrix are shown in Table 3 to Table 5 .

Table 3 The weight judgment matrix of Criterion layer

\begin{tabular}{lcccccc}
\hline & \multicolumn{7}{c}{ Weight judgment matrix } \\
\cline { 2 - 6 } Criterion layer & {$[1]$} & {$[2]$} & {$[3]$} & {$[4]$} & {$[5]$} & Weights \\
\hline [1] 5\% $\mathrm{Na}_{2} \mathrm{SO}_{4}$ solution (B1) & 1 & 2 & 3 & 5 & 7 & 0.440 \\
{$[2] \mathrm{pH}=1 \mathrm{H}_{2} \mathrm{SO}_{4}$ solution (B2) } & $1 / 2$ & 1 & 2 & 4 & 5 & 0.275 \\
{$[3] \mathrm{pH}=2 \mathrm{H}_{2} \mathrm{SO}_{4}$ solution (B3) } & $1 / 3$ & $1 / 2$ & 1 & 2 & 3 & 0.151 \\
{$[4] \mathrm{pH}=3 \mathrm{H}_{2} \mathrm{SO}_{4}$ solution (B4) } & $1 / 5$ & $1 / 4$ & $1 / 2$ & 1 & 1 & 0.073 \\
{$[5] \mathrm{pH}=4 \mathrm{H}_{2} \mathrm{SO}_{4}$ solution (B5) } & $1 / 7$ & $1 / 5$ & $1 / 3$ & 1 & 1 & 0.060 \\
$\lambda_{\max }=5.0356, C R=0.0079<0.1$ & & & & & & \\
\hline
\end{tabular}

Table 4 The weight judgment matrix of Index layer

\begin{tabular}{lccccc}
\hline & \multicolumn{5}{c}{ Weight judgment matrix } \\
\cline { 2 - 5 } Index layer & {$[1]$} & {$[2]$} & {$[3]$} & {$[4]$} & Weights \\
[1] Hardness (C1) & 1 & 2 & $1 / 5$ & 3 & 0.184 \\
[2] Ultrasonic velocity (C2) & $1 / 2$ & 1 & $1 / 4$ & 5 & 0.170 \\
[3] Water absorption capillary (C3) & 5 & 4 & 1 & 7 & 0.588 \\
[4] Weight (C4) & $1 / 3$ & $1 / 5$ & $1 / 7$ & 1 & 0.057 \\
$\lambda_{\max }=4.2539, C R=0.0940<0.1$ & & & & & \\
\hline
\end{tabular}

Table 5 Results of comprehensive weights by AHP

\begin{tabular}{ccccc}
\hline Criterion layer & $\begin{array}{l}\text { Criterion layer } \\
\text { weight } W_{2 i}\end{array}$ & Index layer & $\begin{array}{l}\text { Index layer } \\
\text { weight } W_{1 i}\end{array}$ & $\begin{array}{l}\text { Comprehensive } \\
\text { weight }\end{array} W_{n}=W_{1 i} \times W_{2 i}$ \\
\hline & & $\mathrm{C} 1$ & 0.184 & 0.081 \\
B1 & 0.440 & $\mathrm{C} 2$ & 0.170 & 0.075 \\
& & $\mathrm{C} 3$ & 0.588 & 0.259 \\
& & $\mathrm{C} 4$ & 0.057 & 0.025 \\
\hline
\end{tabular}

\section{$179 \quad$ 4.3 Determine the assessment set and membership degree}

180 Evaluation set refers to the set composed of the evaluation grade of the possibility of evaluation target

181 as the element, $V=\left[v_{1}, v_{2}, v_{3}, \ldots, v_{n}\right]$. Generally, weathering degree is divided into five levels generally, 
182 i.e., no weathering, low weathering, moderate weathering, high weathering and very high weathering 183 in Geologically. Moreover, the risk is generally scaled from $0(0 \%)$ to $1(100 \%)$ in mathematically. 184 Combined with the expert opinion and the classification standard of weathering degree in engineering 185 geology, assessment set is illustrated as following in this study.

$$
\mathrm{V}=\left[\mathrm{v}_{1}, \mathrm{v}_{2}, \mathrm{v}_{3}, \mathrm{v}_{4}, \mathrm{v}_{5}\right]
$$

where $\mathrm{v}_{1}=[0.7,1.0], \mathrm{v}_{2}=[0.5,0.7), \mathrm{v} 3=[0.3,0.5), \mathrm{v} 4=[0.1,0.3), \mathrm{v} 5=[0,0.1)$

In addition, the membership function, including intuitive method, inferential method, F statistical method and Gaussian distribution et al., is established according to the characteristics of the index system. Furthermore, the triangular membership function is selected in this article because the membership function is equivalent to the evaluation result, which has been successfully applied in the risk assessment of earthen sites in China by Yumin (2019) and Zhiqian (2016). In addition, the fuzzy set is generated using triangular membership function (Fig. 10), as shown in Equation (14):

$$
\begin{aligned}
& r_{m 1}=\left\{\begin{array}{l}
1, \\
\frac{f-0.6}{0.25},
\end{array}\right. \\
& f \geq 0.85 \\
& 0.6<f<0.85 \\
& f<0.6 \\
& r_{m 2}=\left\{\begin{array}{l}
0, \\
\frac{0.85-f}{0.25}, \\
\frac{f-0.4}{0.2},
\end{array}\right. \\
& f \geq 0.85 \\
& r_{m 3}=\left\{\begin{array}{l}
0, \\
\frac{0.6-f}{0.2}, \\
\frac{f-0.2}{0.2},
\end{array}\right. \\
& \begin{array}{r}
f \geq 0.6 \\
0.4 \ll f<0.6 \\
0.2 \leq f<0.4 \\
f<0.2
\end{array} \\
& r_{m 5}=\left\{\begin{array}{l}
1, \\
\frac{0.2-f}{0.15}, \\
0,
\end{array}\right. \\
& r_{m 4}=\left\{\begin{array}{l}
0, \\
\frac{0.4-f}{0.2}, \\
\frac{f-0.05}{0.15},
\end{array}\right. \\
& 0.6 \ll f<0.85 \\
& 0.4 \leq f<0.6 \\
& f<0.4 \\
& f<0.05 \\
& 0.05 \leq f<0.2 \\
& f>0.2
\end{aligned}
$$

where $f$ is normalized value of each alternative. 


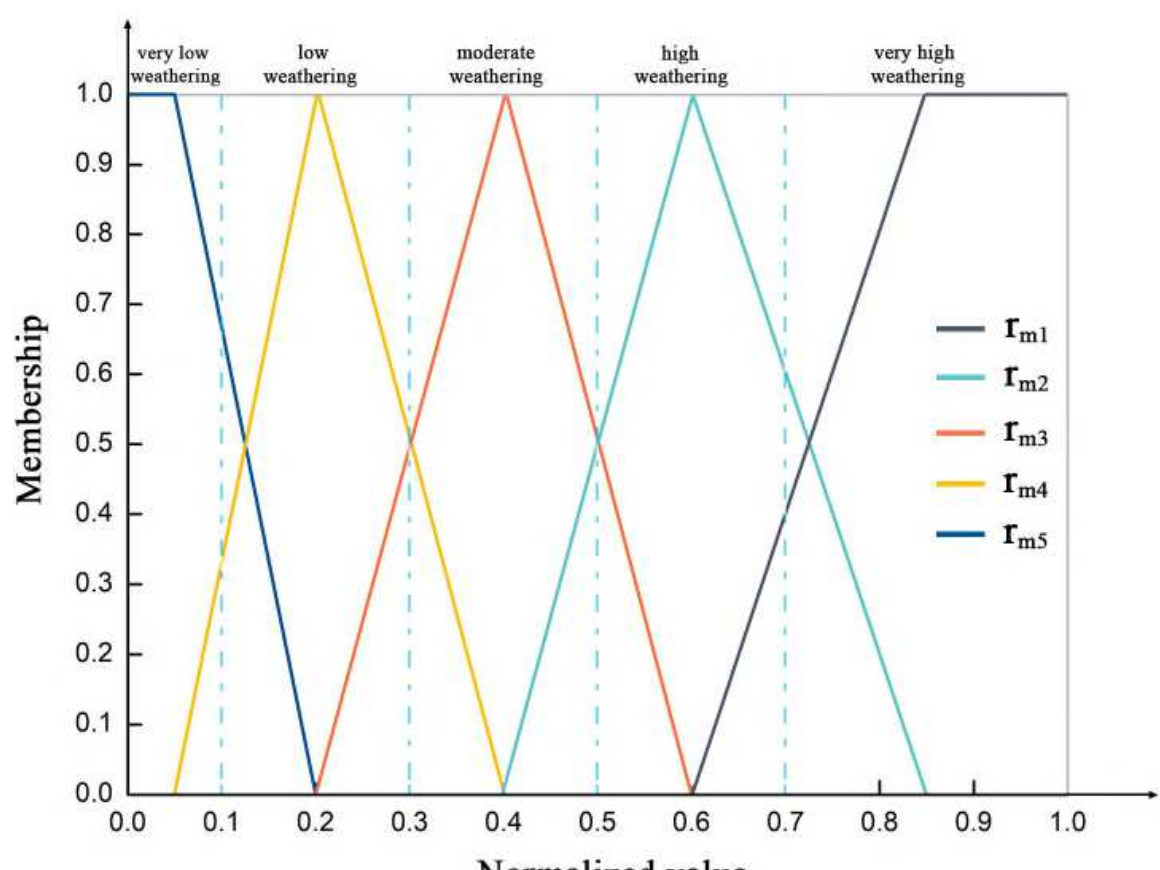

195

196

Fig. 10 Triangle membership function.

\subsection{Calculate the comprehensive assessment}

To carry out the assessment of weathering degree, establishing decision matrix (D) is necessary. The decision matrix and its normalized result $(\mathrm{F})$ are as followed.

$$
D=\left[\begin{array}{c}
618,2629,1.90,2531 \\
591,2446,2.05,2525 \\
564,2187,1.30,2528 \\
483,2037,1.50,2525 \\
468,1895,1.20,2512 \\
425,1817,1.40,2501 \\
385,1738,1.05,2499
\end{array}\right]
$$$$
F=\left[\begin{array}{l}
0.175,0.178,0.183,0.144 \\
0.167,0.166,0.197,0.143 \\
0.160,0.148,0.125,0.143 \\
0.137,0.138,0.144,0.143 \\
0.132,0.128,0.115,0.143 \\
0.120,0.123,0.135,0.142 \\
0.109,0.118,0.101,0.142
\end{array}\right]
$$

Then, the membership can be calculated according Eqs. (14) and Fig. 10:

$$
R_{1}=\left[\begin{array}{c}
0,0,0,0.3933,0.6067 \\
0,0,0,0.4533,0.5467 \\
0,0,0,0.3400,0.6600 \\
0,0,0,0.6133,0.3867
\end{array}\right]
$$

Therefore, the comprehensive vector of Index layer and the evaluation vector of criterion layer are obtained by Eqs. (5) and (6) respectively, as shown in Equation (15) :

$$
B=[0,0,0,0.3843,0.6147]^{\mathrm{T}}
$$

In addition, evaluation vector of goal layer (T) can be calculated according to Eqs. (12) :

$$
T=[0,0,0,0.1691,0.2705]
$$

Finally, the value of weathering degree 
$209 K=T \times S^{T}=[0,0,0,0.1691,0.2705] \times[0.05,0.2,0.4,0.6,0.85]^{T}=0.3271$, which belongs to low weathering. In 210 addition, the weight judgement matrix of Index layer and comprehensive weights under other 211 conditions are shown in Table 6 or Table 7.

Table 6 The weight judgement matrix of Index layer under other conditions

\begin{tabular}{|c|c|c|c|c|c|}
\hline \multirow{2}{*}{ Index layer } & \multicolumn{4}{|c|}{ Weight judgment matrix } & \multirow[b]{2}{*}{ Weights } \\
\hline & [1] & {$[2]$} & [3] & [4] & \\
\hline \multicolumn{6}{|l|}{$\mathrm{pH}=1 \mathrm{H}_{2} \mathrm{SO}_{4}$ solution $(\mathrm{B} 2)$} \\
\hline [1] Hardness (C1) & 1 & 5 & 8 & 6 & 0.626 \\
\hline [2] Ultrasonic velocity (C2) & $1 / 5$ & 1 & 3 & 5 & 0.221 \\
\hline [3] Water absorption capillary (C3) & $1 / 8$ & $1 / 3$ & 1 & 2 & 0.090 \\
\hline [4] Weight (C4) & $1 / 6$ & $1 / 5$ & $1 / 2$ & 1 & 0.064 \\
\hline \multicolumn{6}{|l|}{$\lambda_{\max }=4.2208, C R=0.0082<0.1$} \\
\hline \multicolumn{6}{|l|}{$\mathrm{pH}=2 \mathrm{H}_{2} \mathrm{SO}_{4}$ solution $(\mathrm{B} 3)$} \\
\hline [1] Hardness (C1) & 1 & 3 & 6 & 7 & 0.568 \\
\hline [2] Ultrasonic velocity (C2) & $1 / 3$ & 1 & 4 & 5 & 0.277 \\
\hline [3] Water absorption capillary (C3) & $1 / 6$ & $1 / 4$ & 1 & 2 & 0.094 \\
\hline [4] Weight (C4) & $1 / 7$ & $1 / 5$ & $1 / 2$ & 1 & 0.061 \\
\hline \multicolumn{6}{|l|}{$\lambda_{\max }=4.0922, C R=0.0370<0.1$} \\
\hline \multicolumn{6}{|l|}{$\mathrm{pH}=3 \mathrm{H}_{2} \mathrm{SO}_{4}$ solution $(\mathrm{B} 4)$} \\
\hline [1] Hardness (C1) & 1 & 3 & 4 & 5 & 0.531 \\
\hline [2] Ultrasonic velocity (C2) & $1 / 3$ & 1 & 2 & 4 & 0.245 \\
\hline [3] Water absorption capillary (C3) & $1 / 4$ & $1 / 2$ & 1 & 3 & 0.153 \\
\hline [4] Weight (C4) & $1 / 5$ & $1 / 4$ & $1 / 3$ & 1 & 0.072 \\
\hline \multicolumn{6}{|l|}{$\lambda_{\max }=4.1179, C R=0.0437<0.1$} \\
\hline \multicolumn{6}{|l|}{$\mathrm{pH}=4 \mathrm{H}_{2} \mathrm{SO}_{4}$ solution $(\mathrm{B} 5)$} \\
\hline [1] Hardness (C1) & 1 & 2 & 4 & 5 & 0.501 \\
\hline [2] Ultrasonic velocity (C2) & $1 / 2$ & 1 & 2 & 3 & 0.264 \\
\hline [3] Water absorption capillary (C3) & $1 / 4$ & $1 / 2$ & 1 & $1 / 2$ & 0.106 \\
\hline [4] Weight (C4) & $1 / 5$ & $1 / 3$ & 2 & 1 & 0.129 \\
\hline
\end{tabular}




$$
\lambda_{\max }=4.1327, C R=0.0490<0.1
$$

Table 7 Comprehensive weights of other conditions

\begin{tabular}{|c|c|c|c|c|}
\hline Criterion layer & $\begin{array}{l}\text { Criterion layer } \\
\text { weight } W_{2 i}\end{array}$ & Index layer & $\begin{array}{ll}\text { Index } & \text { layer } \\
\text { weight } & W_{1 i} \\
\end{array}$ & $\begin{array}{l}\text { Comprehensive } \\
\text { weight } W_{n}=W_{1 i} \times W_{2 i}\end{array}$ \\
\hline \multirow{4}{*}{ B2 } & \multirow{4}{*}{0.275} & $\mathrm{C} 1$ & 0.626 & 0.172 \\
\hline & & $\mathrm{C} 2$ & 0.221 & 0.061 \\
\hline & & C3 & 0.090 & 0.025 \\
\hline & & $\mathrm{C} 4$ & 0.064 & 0.018 \\
\hline \multirow{4}{*}{ B3 } & \multirow{4}{*}{0.151} & $\mathrm{C} 1$ & 0.568 & 0.086 \\
\hline & & $\mathrm{C} 2$ & 0.277 & 0.042 \\
\hline & & C3 & 0.094 & 0.014 \\
\hline & & $\mathrm{C} 4$ & 0.061 & 0.009 \\
\hline \multirow{4}{*}{ B4 } & \multirow{4}{*}{0.073} & $\mathrm{C} 1$ & 0.531 & 0.039 \\
\hline & & $\mathrm{C} 2$ & 0.245 & 0.018 \\
\hline & & $\mathrm{C} 3$ & 0.153 & 0.011 \\
\hline & & $\mathrm{C} 4$ & 0.072 & 0.005 \\
\hline \multirow{4}{*}{ B5 } & \multirow{4}{*}{0.060} & $\mathrm{C} 1$ & 0.501 & 0.030 \\
\hline & & $\mathrm{C} 2$ & 0.264 & 0.016 \\
\hline & & $\mathrm{C} 3$ & 0.106 & 0.006 \\
\hline & & $\mathrm{C} 4$ & 0.129 & 0.008 \\
\hline
\end{tabular}

214 Note: $\mathrm{B} 2$ represent $\mathrm{pH}=1$ sulfuric acid, $\mathrm{B} 3$ represent $\mathrm{pH}=2$ sulfuric acid, $\mathrm{B} 4$ represent $\mathrm{pH}=3$ sulfuric acid and $\mathrm{B} 5$ is $\mathrm{pH}=4$ sulfuric acid.

215 Likewise, the value of other conditions is 0.1951 for $\mathrm{pH}=1$ sulfuric acid, 0.1060 for $\mathrm{pH}=2$ sulfuric 216 acid, 0.0516 for $\mathrm{pH}=3$ sulfuric acid and 0.0421 for $\mathrm{pH}=4$ sulfuric acid, as shown in Fig. 11 . 


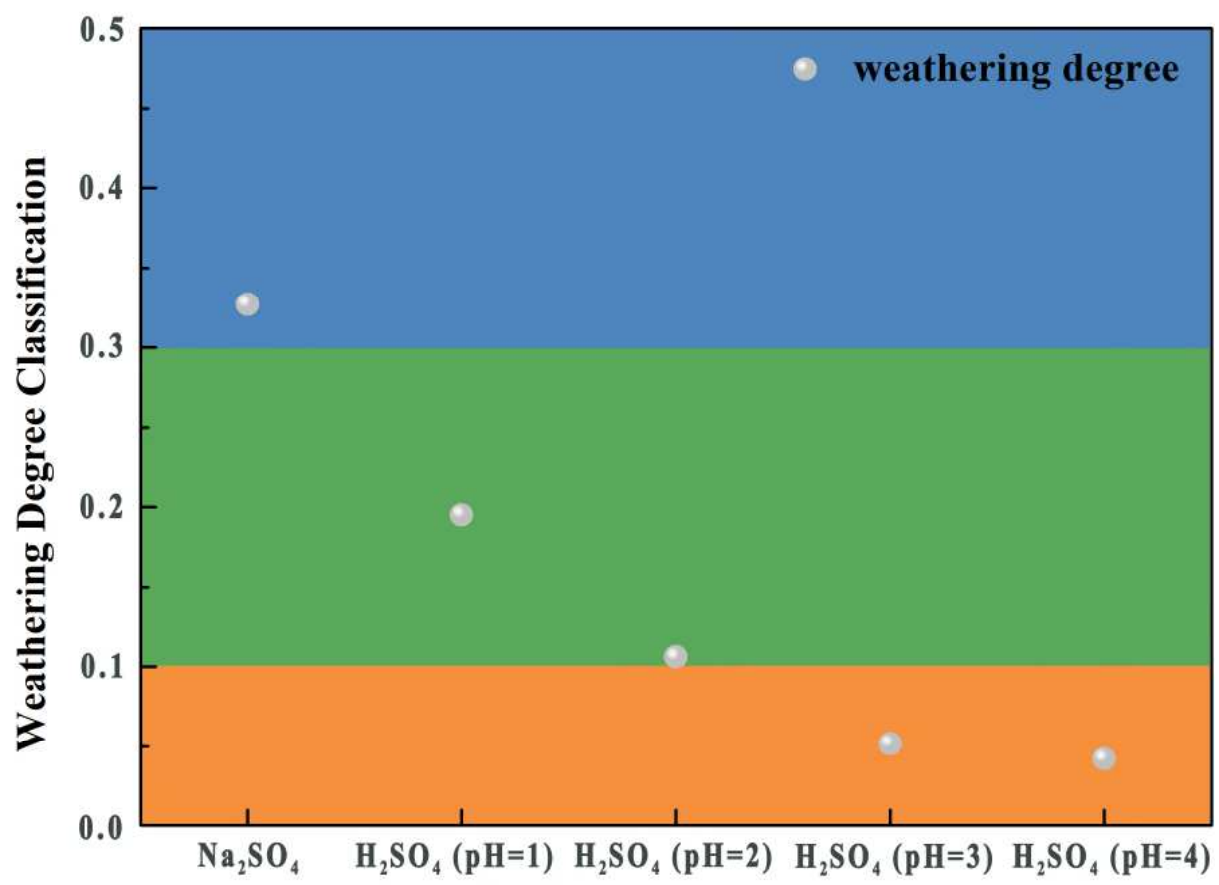

Fig. 11 Comprehensive weathering degree results.

\section{Discussion}

Rock weathering is due to the complex interplay of physical and chemical processes which are far from being well understood (Turkington and Paradise, 2005). The petrophysical properties such as 223 (Ruedrich and Siegesmund, 2006).

\subsection{Grain fabric}

225 As presented in Fig. 12, petrographic analyses (in cross-polarized light) and Scanning Electron 226 Microscope test on standard thin sections were performed for a qualitative description of the fresh rock 227 fabric with different magnification.

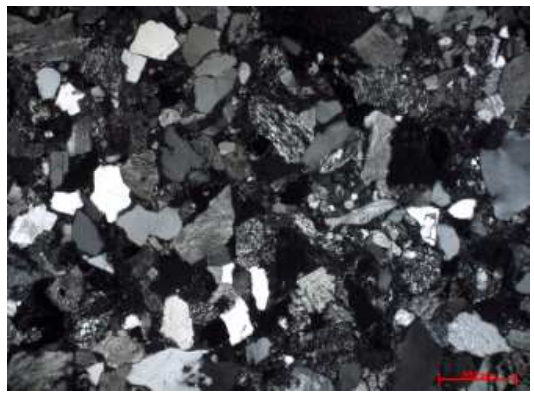

(a)

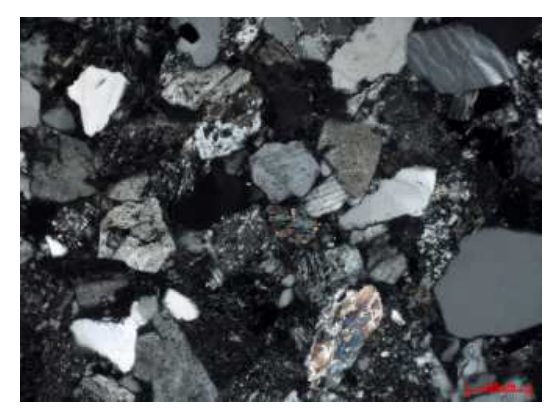

(b)

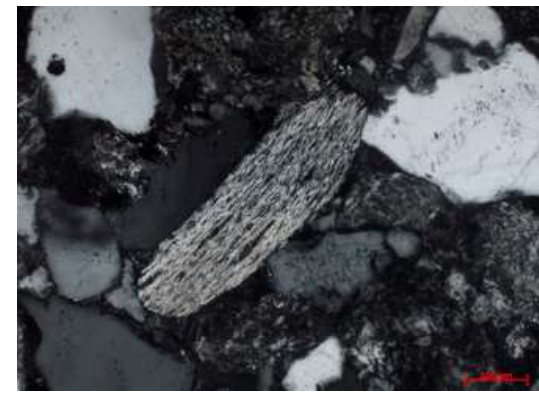

(c) 


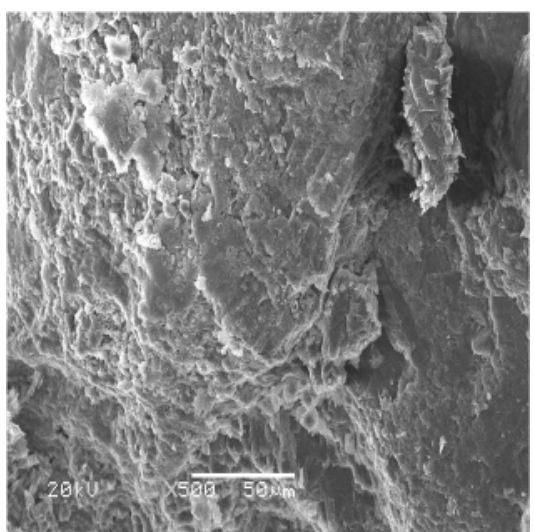

(d)

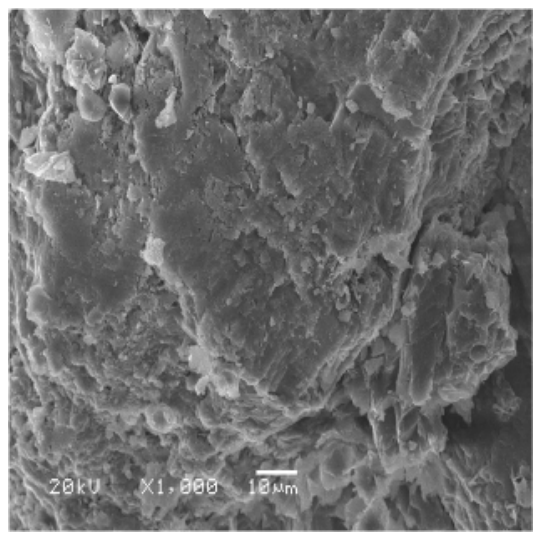

(e)

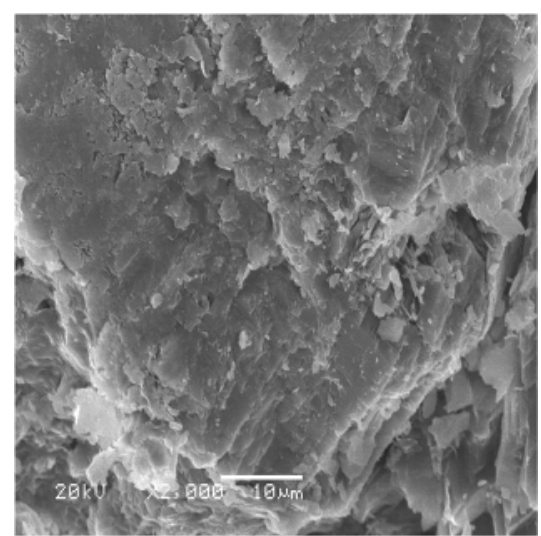

(f)

Fig. 12 Petrographic and SEM observation under different magnification. (a) $\times 50$ magnification; (b) $\times 100$ magnification; (c) $\times 200$ magnification; (d) $\times 500$ magnification; (e) $\times 1000$ magnification; (f) $\times 2000$ magnification.

From Fig. 12, observation in cross-polarized light reveal that grains exhibit a preferred orientation in a oblate or prolate shape, and little gypsum cements occur. While the microstructure is characterized by layered arrangement and tight cementation between particles. Slight erosion has been performed at the boundary of each layer. In addition, the separate effects of either erosion, hydration action and salt crystallization of acid-rich/salt-rich water, will further lead to the deterioration within rock mass. It is clearly observed in Fig. 13 under different magnification. For example, samples soaked in sodium sulphate (Fig. 13a, b and c) performed big dissolution pores, which provide the channel allowing saltrich fluid enter to conduct the hydration and crystallization action. In contrast, samples immersed in dilute sulfuric acid solution is characterized by micro-cracking, it is obvious in Fig. 13f. Moreover, the white calcium sulfate crystals are clearly observed on mineral surface (Fig. 13h to l). It is interesting to note that micro-cracking and small-scale cavities (Fig. 131) have been development on the mineral surface, which is likely to result in the fracture of mineral crystal and with the loss of aqueous solution.
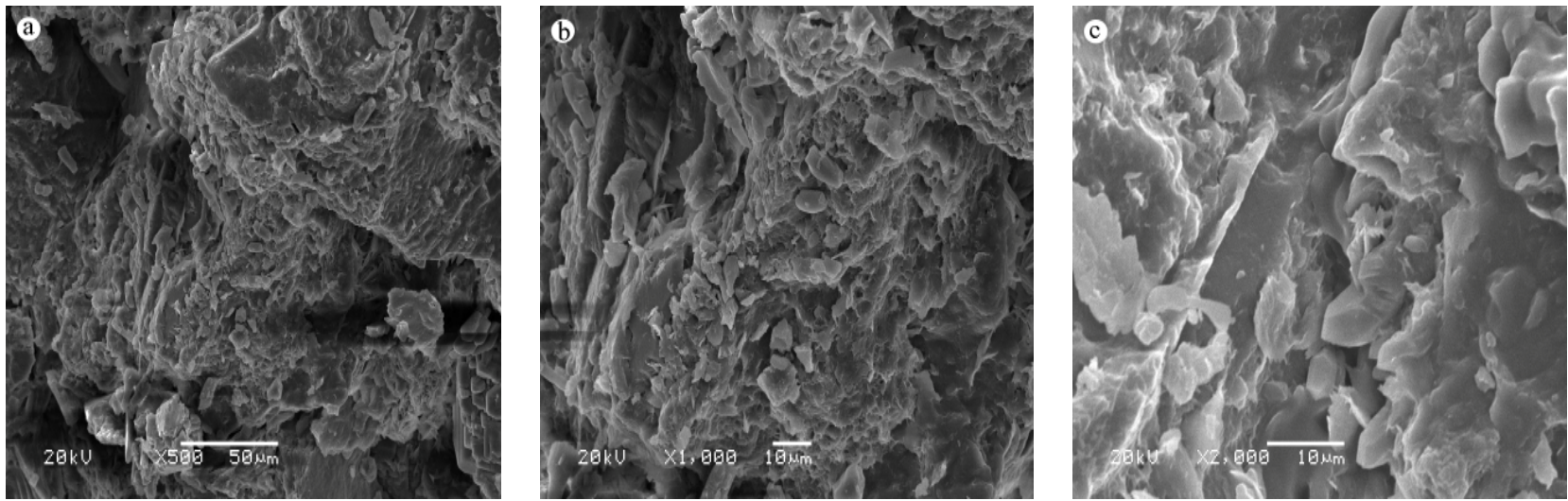

SEM images of specimens under the efflorescences of mirabilite 

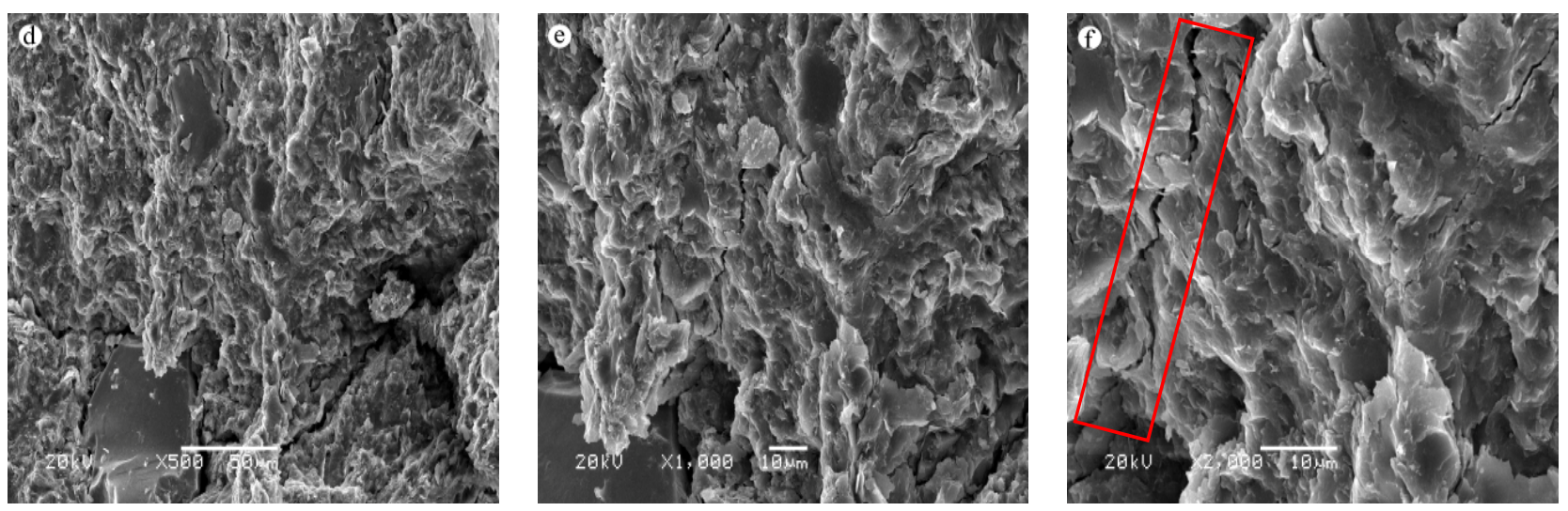

SEM images of specimens under the acid deterioration $(\mathrm{pH}=1)$
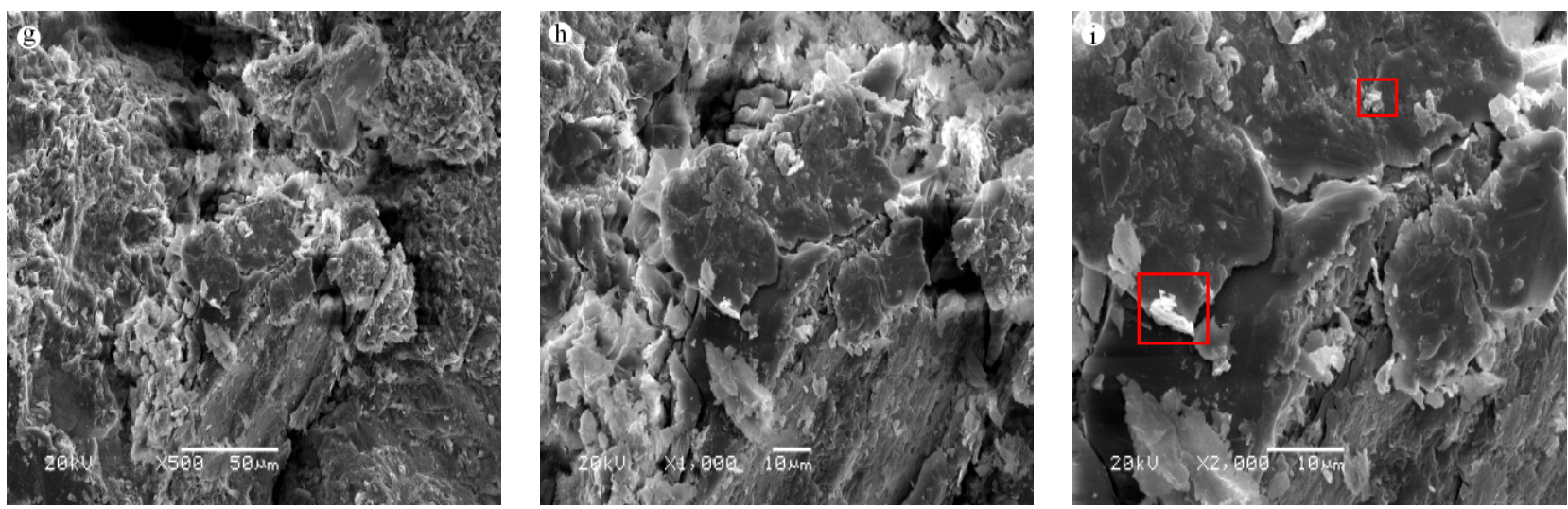

SEM images of specimens under the acid deterioration $(\mathrm{pH}=2)$
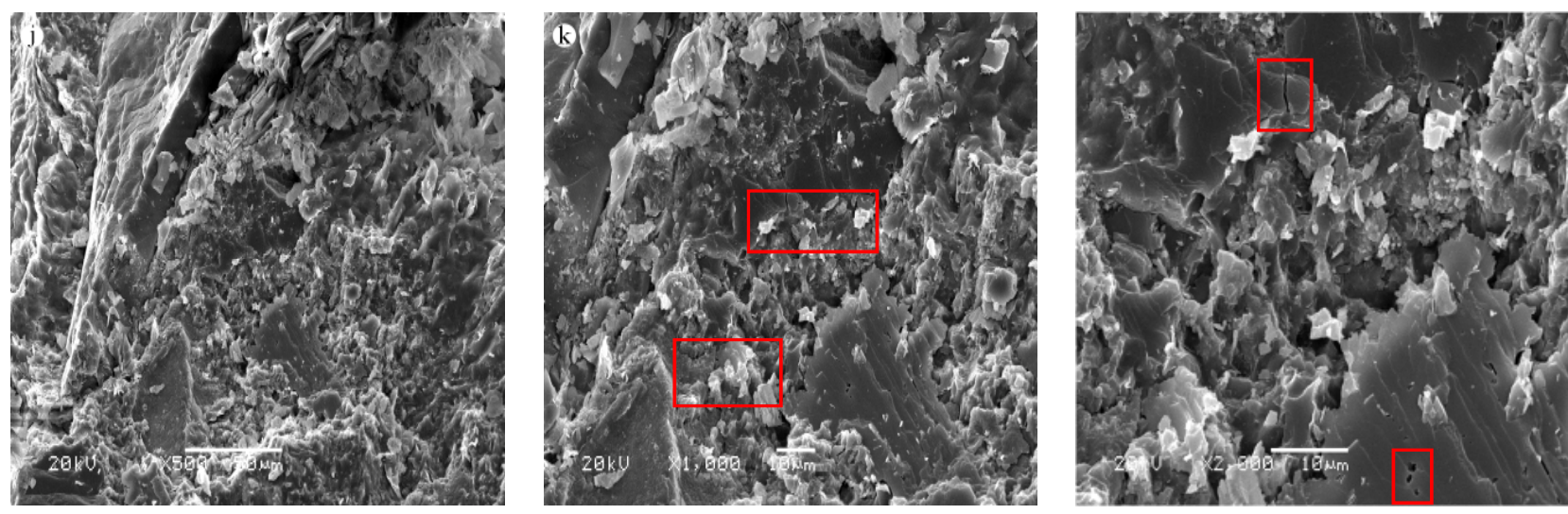

SEM images of specimens under the acid deterioration $(\mathrm{pH}=3)$
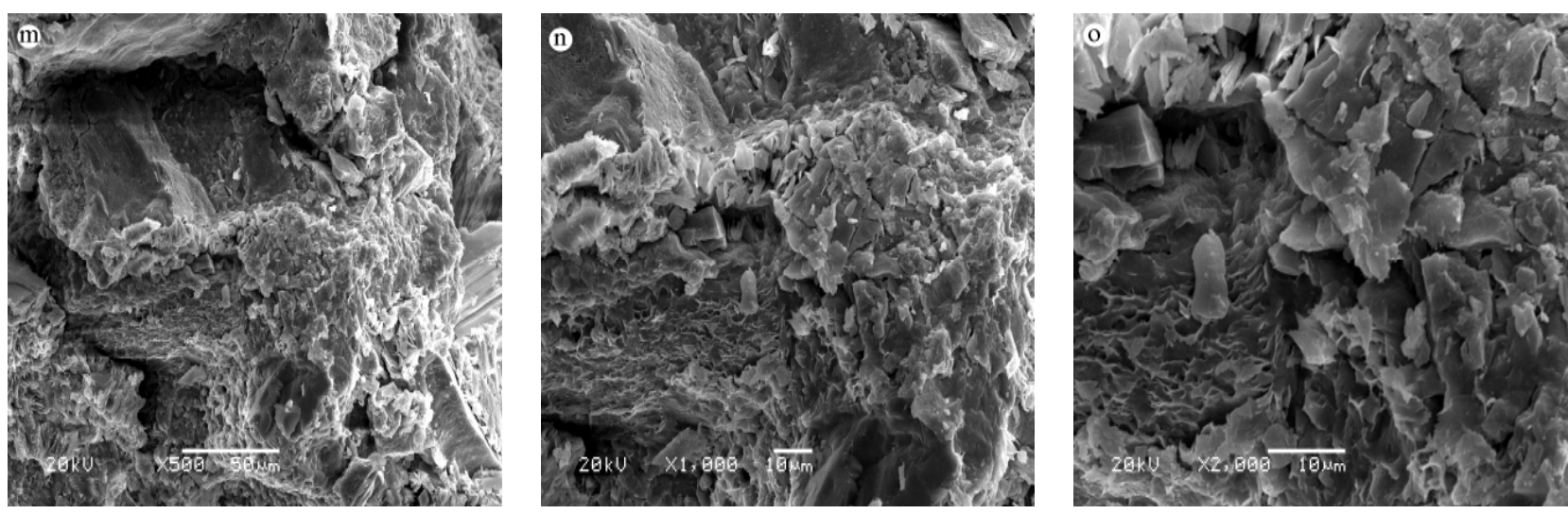

SEM images of specimens under the acid deterioration $(\mathrm{pH}=4)$ 
Fig. 13 SEM images after simulation deterioration experiment. (a), (b), (c) samples damaged by salt solution; (d), (e), f samples soaked in diluted sulfuric acid solution ( $\mathrm{pH}=1)$; ( $\mathrm{g}$ ), (h), (i) samples soaked in diluted sulfuric acid solution ( $\mathrm{pH}=2$ ); ( $\mathrm{j}),(\mathrm{k})$, (l) dilute sulfuric acid solution with $\mathrm{pH}=3$ and $\mathrm{m}, \mathrm{n}, \mathrm{o}$ is the dilute sulfuric acid solution with $\mathrm{pH}=4$.

\subsection{Pore size distribution}

The pore size distribution of samples is determined by using mercury porosimetry (Brakel et al.1981), as shown in Fig. 14. Experiment results reveal that the medium porosity of the Jurassic sandstone varies between 8.01 percent for the fresh sandstone and 14.20 percent for the sandstone undergoing the deterioration process. The porosity of specimens varies from high to low is in the following order: samples immersed in soldium sulphate solution, samples soaked in sulfuric acid solution with $\mathrm{pH}=2$, samples soaked in sulfuric acid solution with $\mathrm{pH}=1$, samples immersed in sulfuric acid solution with $\mathrm{pH}=3$, fresh sandstone and samples immersed in sulfuric acid solution with $\mathrm{pH}=4$.

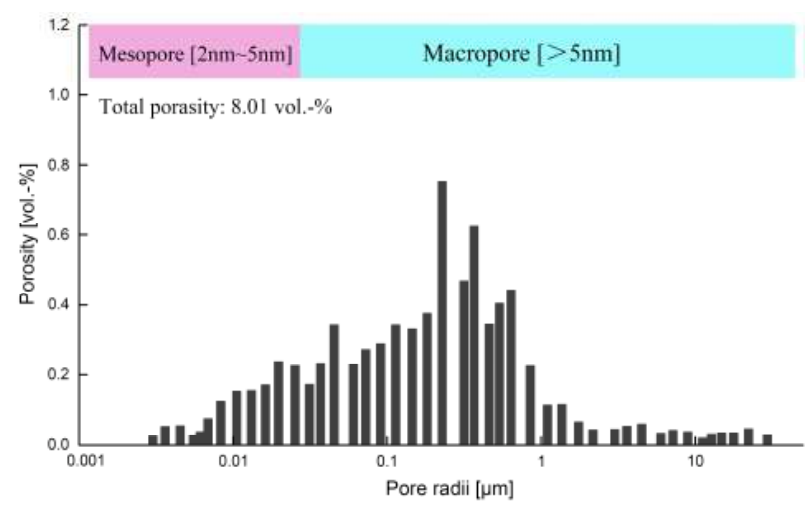

(a)

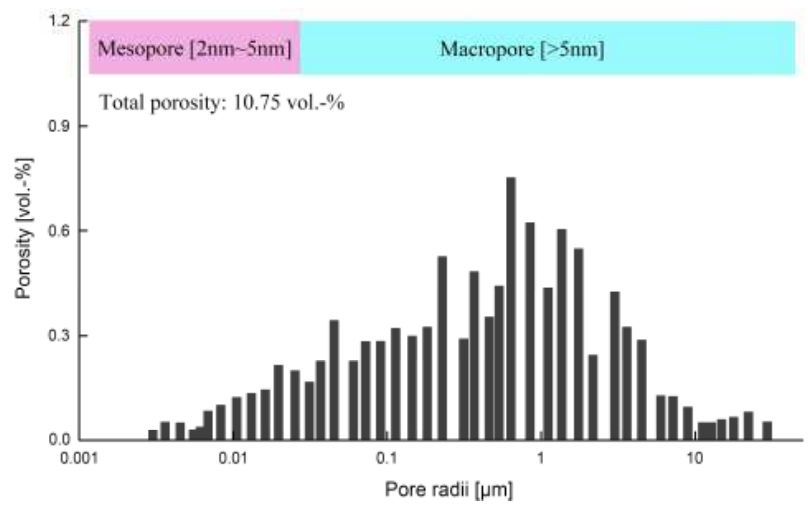

(c)

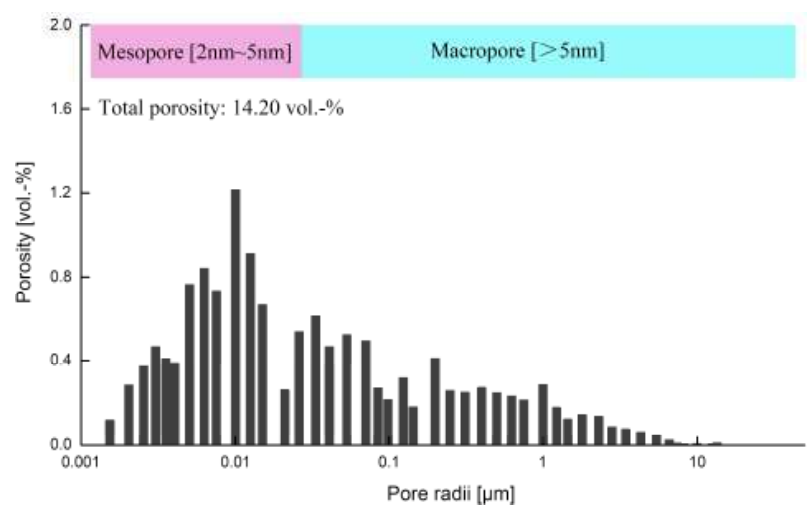

(b)

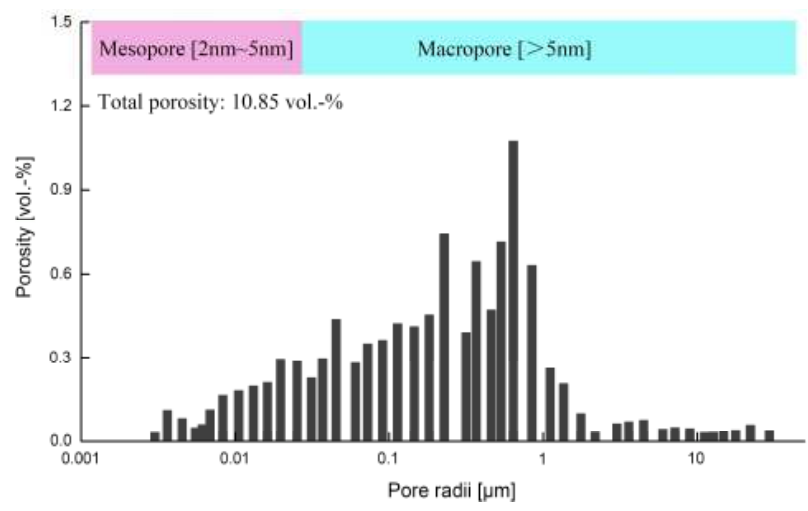

(d) 


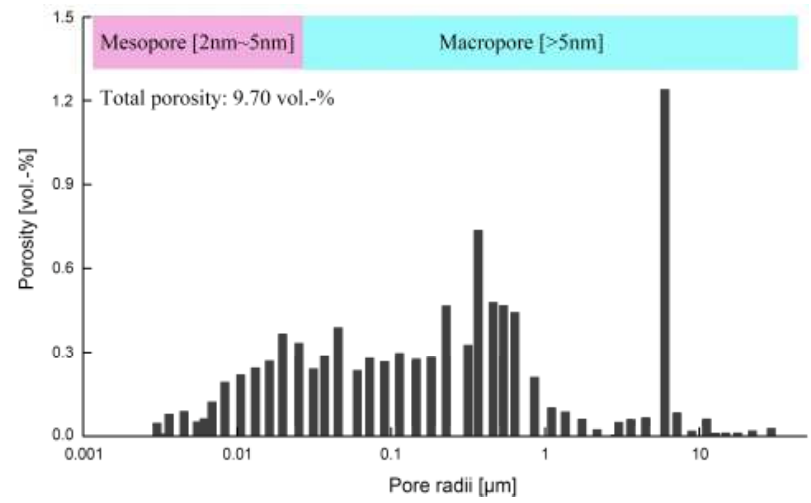

(e)

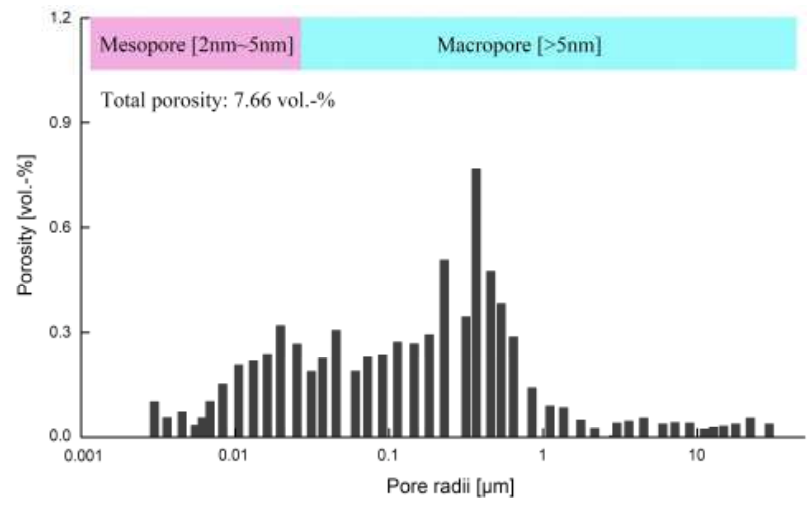

(f)

Fig. 14 Pore size distribution of the investigated samples, measured by mercury porosimetry. (a) Fresh sample; (b) Sample immersed in soldium sulphate solution; (c) Sample immersed in sulfuric acid solution with $\mathrm{pH}=1$; (d) Sample immersed in sulfuric acid solution with $\mathrm{pH}=2$; (e) Sample immersed in sulfuric acid solution with $\mathrm{pH}=3$; $\mathrm{f}-\mathrm{Sample}$ immersed in sulfuric acid solution with $\mathrm{pH}=4$.

It is clearly to obtain that samples under soldium sulphate solution degradation perform highest porosity, although the cycle of salt solution is shorter than the cycle of acid solution. Samples soaked in sulfuric acid performe a good correlation between porosity and weathering degree. In general, porosity of samples with hydrogen ions concentration of $\mathrm{pH}=1$ and $\mathrm{pH}=2$ is larger than that $\mathrm{pH}=3$ and $\mathrm{pH}=4$. Correspondingly, weathering degree of samples are higher over hydrogen ion concentration increase. The value of weathering degree is 0.1951 for samples soaked in $\mathrm{pH}=1$ sulfuric acid solution and, $0.1060,0.0516$ or 0.0421 for sampled soaked in $\mathrm{pH}=2, \mathrm{pH}=3, \mathrm{pH}=4$ sulfuric acid solution respectively.

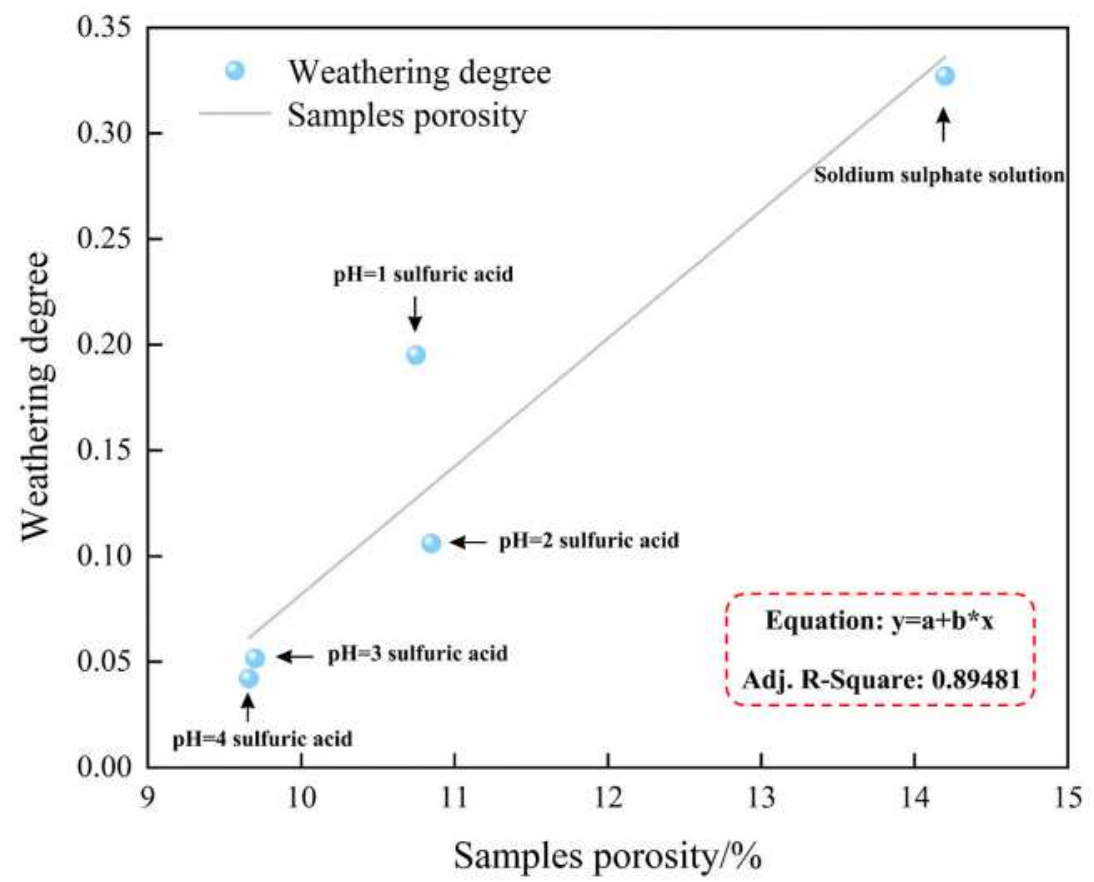

Fig. 15 Relationship between samples porosity and weathering degree. 
For sulfuric acid deterioration experiment, damage usually occurs in the surface layer of samples, which characterized by disintegration macroscopically and mic-cracking on partical surface at the microlevel. Results of Non-destructive testing reveal that surface hardness and ultrasonic velocity decrease over testing cycle. The decay rate increases with increasing hydrogen ion concentration. However, soldium sulphate solution appears to be able to penetrate the interior of the specimen and cause damage, which characterized by delamination and disintegration. This has been attributed in pore expansion and connectivity, which can be confirmed by the change of porosity. On the other hand, stress development by growth of crystal, thermal expansion and hydration also play important role in deterioration process (Miyazaki et al.1992; Schmelzer et al. 2006; Winkler and Wilhelm, 1970). Therefore, the weathering degree performed sever than samples with sulfuric acid damage.

In addition, much work have done on relationship between compressive strength and porosity (Ruedrich et al. 2010). This study show a positive correlation between porosity and weathering degree (Fig. 15). There is no doubt that porosity is a very important rock mechanics parameter. It is also a very effective tool for establishing links between rock physics, hydraulics and mechanical indicators. Based on rock porosity, we will try to consider more weathering factors in future studies to develop more detailed weathering models.

\section{Conclusions}

According to analysis of AHP-Fuzzy assessment method and petrophysical properties, some major conclusions can be drawn:

(1) The weathering degree of specimens varies from high to low is in the following order: samples immersed in soldium sulphate solution, soaked in sulfuric acid solution with $\mathrm{pH}=1$, soaked in sulfuric acid solution with $\mathrm{pH}=2$, samples immersed in sulfuric acid solution with $\mathrm{pH}=3$, and samples immersed in sulfuric acid solution with $\mathrm{pH}=4$.

(2) Based on Fuzzy-AHP method, samples undergoing salt simulate deterioration process is shown by moderate weathering $(0.3271)$, low weathering for $\mathrm{pH}=1$ sulfuric acid $(0.1951)$ and $\mathrm{pH}=2$ sulfuric acid (0.1060), very low weathering for $\mathrm{pH}=3$ (0.0516) and/or 4 sulfuric acid (0.0421).

(3) According to petrophysical analysis, comprehensive strength and porosity perform a clear correlation to weathering resistance, which higher moisture content exhibit lower comprehensive strength. In addition, samples with higher porosity is shown by the lower weathering resistance.

(4) Based on SEM observation under different magnification, microstructure is characterized by layer arrangement and slight erosion, which performed at the boundary of each layer 
(5) Quantitative evaluation of weathering degree plays an important role in preventive conservation. Additionally, it should be emphasized that steady environment monitoring at sites are required as well.

Acknowledgements We gratefully acknowledge the support from the National Key Research and Development Program of China (2019YFC1520602).

Authors' contributions Mingshen Shao proposed and drafted the manuscript. Dong Xu and Yuchao Wang carried out simulated experiments. Ziyi Wang and Xingzhou Liang supported in data collected and analysis. Li Li has contributed in results and discussion part. All authors revised and approved the final manuscript.

Availability of data and materials Not applicable.

\section{Declarations}

Conflicts of interest The author declares no conflict of interest.

\section{References}

Alexandrowicz Z (1989) Evolution of weathering pits on sandstone tors in the Polish Carpathians. Zeitschrift für Geomorphologie, 33(3), 275-289. https://doi.org/10.1127/zfg/33/1989/275

Alshehri SA, Rezgui Y, Li H (2015) Disaster community resilience assessment method: a consensus-based Delphi and AHP approach. Nat Hazards, 78(1), 395-416. https://doi.org/10.1007/s11069-015-1719-5

Brakel JV, Modry S, Svata M (1981) Mercury porosimetry : state of the art. Powder Technol 29,1-12. https://doi.org/10.1016/0032-5910(81)85001-2

Chiu CF, Ng CWW (2014) Relationships between chemical weathering indices and physical and mechanical properties of decomposed granite. Eng Geol, 179, 76-89. https://doi.org/10.1016/j.enggeo.2014.06.021

Dong X, Yusong D, Shuling W, Shuwen D, Chongfa C (2015) Fractal features of soil particle-size distribution of different weathering profiles of the collapsing gullies in the hilly granitic region, south China. Nat Hazards, 79(1), 455-478. https://doi.org/10.1007/s11069-015-1852-1

Ercanoglu M, Kasmer O, Temiz N (2008) Adaptation and comparison of expert opinion to analytical hierarchy process for landslide susceptibility mapping. B Eng Geol Environ, 67(4), 565-578. https://doi.org/10.1007/s10064-008-0170-1

Hategekimana Y, Lijun Y, Yuping N, Jianfeng Z, Fang L, Fei Guo (2018) Integration of multi-parametric fuzzy analytic hierarchy process and GIS along the UNESCO World Heritage: a flood hazard index, Mombasa County, 
Kenya. Nat Hazards, 92(2), 1137-1153. https://doi.org/10.1007/s11069-018-3244-9

Jingke Z, Zhen L, Li L, Jianhui L, Dun L, Mingshen S (2021) Study on weathering mechanism of sandstone statues in Southwest China: example from the sandstone of Niche of Sakyamuni Entering Nirvana at Dazu Rock Carvings. Nat Hazards. https://doi.org/10.1007/s11069-021-04705-w

Lanqing W, Dongshuai H, Huaishuai S, Tiejun Z (2018) Molecular dynamics study on the Tri-calcium silicate hydration in sodium sulfate solution: Interface structure, dynamics and dissolution mechanism. Constr Build Mater, 170, 402-417. https://doi.org/10.1016/j.conbuildmat.2018.03.035

Murru A, Freire-Liata DM, Fort R, Varas-Muriel MJ, Meloni P (2018) Evaluation of post-thermal shock effects in Carrara marble and Santa Caterina di Pittinuri limestone. Constr Build Mater, 186, 1200-1211. https://doi.org/10.1016/j.conbuildmat.2018.08.034

Martinho E, Mendes M, Dionísio A (2017) 3D imaging of P-waves velocity as a tool for evaluation of heat induced limestone decay. Constr Build Mater, 135, 119-128. https://doi.org/10.1016/j.conbuildmat.2016.12.192

Mellor A, Short J, Kirkby SJ (1997) Tafoni in the El Chorro area, Andalucia, southern spain. Earth Surf Proc Land, 22, 817-833. https://doi.org/10.1002/(sici)1096-9837(199709)22:9<817::aid-esp768>3.0.co;2-t

Miyazaki N, Uchida H, Munakata T, Fujioka K, Sugino Y (1992) Thermal stress analysis of silicon bulk single crystal during Czochralski growth. J Cryst Growth, 125(1-2), 102-111. doi:https://doi.org/10.1016/0022$\underline{0248(92) 90325-\mathrm{D}}$

Musso Piantelli F, Herwegh M, Anselmetti FS, Waldvogel M, Gruner U (2020) Microfracture propagation in gneiss through frost wedging: insights from an experimental study. Nat Hazards, 100(2), 843-860. https://doi.org/10.1007/s11069-019-03846-3

Mustoe GE (1983) Cavernous weathering in the Capitol Reef desert,Utah. Earth Surf Proc Land, 8, 517-526. https://doi.org/10.1002/esp.3290080603

Nefeslioglu HA, Sezer EA, Gokceoglu C, Ayas Z (2013) A modified analytical hierarchy process (M-AHP) approach for decision support systems in natural hazard assessments. Comput Geosci-UK, 59, 1-8. https://doi.org/10.1016/j.cageo.2013.05.010

Ramkar P, Yadav SM (2021) Flood risk index in data-scarce river basins using the AHP and GIS approach. Nat Hazards. https://doi.org/10.1007/s11069-021-04871-x

Rezaei M, Amiraslani F, Samani NN, Alavipanah K (2019) Application of two fuzzy models using knowledge-based and linear aggregation approaches to identifying flooding-prone areas in Tehran. Nat Hazards, 100(1), 363-385. https://doi.org/10.1007/s11069-019-03816-9

Ruedrich J, Bartelsen T, Dohrmann R, Siegesmund S (2010) Moisture expansion as a deterioration factor for 
sandstone used in buildings. Environ Earth Sci, 63(7-8), 1545-1564. https://doi.org/10.1007/s12665-010-07670

Ruedrich J, Siegesmund S (2006) Salt and ice crystallisation in porous sandstones. Environ Geol, 52(2), $225-249$. https://doi.org/10.1007/s00254-006-0585-6

Saaty TL (1979) Applications of analytical hierarchies. Math Comput Simulat, XXI, 1-20. https://doi.org/10.1016/0378-4754(79)90101-0

Saaty TL (2006) Rank from comparisons and from ratings in the analytic hierarchy/network processes. Eur J Oper Res, 168(2), 557-570. https://doi.org/10.1016/j.ejor.2004.04.032

Schmelzer JWP, Zanotto ED, Avramov I, Fokin VM (2006) Stress development and relaxation during crystal growth in glass-forming liquids. J Non-Cryst Solids, 352(5), 434-443. https://doi.org/10.1016/j.jnoncrysol.2006.01.016

Shang G, Zaiyue Z, Cungen C (2010) Calculating weights methods in complete matrices and incomplete matrices. $J$ Softw, 5(3), 304-311. https://doi.org/10.4304/jsw.5.3.304-311

Turkington AV, Paradise TR (2005) Sandstone weathering: a century of research and innovation. Geomorphology, 67(1-2), 229-253. https://doi.org/10.1016/j.geomorph.2004.09.028

Tianbiao P, Wenwu C, Yumin D, Wenjuan L, Na S (2016) Snowfall-related deterioration behavior of the Ming Great Wall in the eastern Qinghai-Tibet Plateau. Nat Hazards, 84(3), 1539-1550. https://doi.org/10.1007/s11069-0162497-4

Wilhelm K, Viles H, Burke Ó (2016) Low impact surface hardness testing (Equotip) on porous surfaces - advances in methodology with implications for rock weathering and stone deterioration research. Earth Surf Proc Land, 41(8), 1027-1038. https://doi.org/10.1002/esp.3882

Wind Y, Satty TL (1980) Marketing applications of the analytic hierarchy process. Manag S, 26(7), 641-658. https://doi.org/10.1287/mnsc.26.7.641

Winkler EM, Wilhelm EJ (1970) Salt burst by hydration pressures in architectural stone in urban atmosphere. Geol Soc Am Bull, 81(2), 567-572. doi:https://doi.org/10.1130/0016-7606(1970)81[567:SBBHPI]2.0.CO;2

Xiaoling Y, Jiehua D, Hui H (2013) Application of a triangular fuzzy AHP approach for flood risk evaluation and response measures analysis. Nat Hazards, 68(2), 657-674. https://doi.org/10.1007/s11069-013-0642-x

Yun W, Xiaozhao L, Zhen Huang, Sen Xue (2021) Effect of temperature on physical, mechanical and acoustic emission properties of Beishan granite, Gansu Province, China. Nat Hazards, 107(2), 1577-1592. https://doi.org/10.1007/s11069-021-04647-3

Y1lmaz NG (2012) The influence of testing procedures on uniaxial compressive strength prediction of carbonate rocks from equotip hardness tester (EHT) and proposal of a new testing methodology: Hybrid Dynamic 
Hardness (HDH). Rock Mech Rock Eng, 46(1), 95-106. https://doi.org/10.1007/s00603-012-0261-y

Yumin D, Wenwu C, Kai C, Kewen Z (2019) Study on damage assessment of earthen sites of the Ming Great Wall in Qinghai province based on Fuzzy-AHP and AHP-TOPSIS. Int J Archit Herit, 14(6), 903-916. https://doi.org/10.1080/15583058.2019.1576241

Zadeh LA (1973) Outline of a new approach to the analysis of complex systems and decision processes. IEEE T Syst Man Cy, SMC-3(1), 28-44. https://doi.org/10.1109/TSMC.1973.5408575

Zhongjian Z, Lihui L, Wenjie X, Yan F, Jun F (2015) Flat-plate roof collapse of shallow caverns and protective measures: a case study of Longyou ancient siltstone caverns. Nat Hazards, 76, 191-213. https://doi.org/10.1007/s11069-014-1481-0)

Zhiqian G, Wenwu C, Jingke Z, Fei Y, Xingzhou L, Faguo H, F., Qinglin G (2016) Hazard assessment of potentially dangerous bodies within a cliff based on the Fuzzy-AHP method: a case study of the Mogao Grottoes, China. 401 